\title{
Invited review: Probiotic yogurt quality criteria, regulatory framework, clinical evidence, and analytical aspects
}

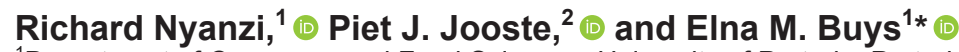 \\ ${ }^{1}$ Department of Consumer and Food Sciences, University of Pretoria, Pretoria 0028, South Africa \\ ${ }^{2}$ Department of Biotechnology and Food Technology, Tshwane University of Technology, Pretoria 0001, South Africa
}

\begin{abstract}
Yogurt is a milk-based product manufactured by lactic acid fermentation enabled by symbiotic yogurt cultures. Yogurt is largely considered to be a health product, and it is employed to deliver probiotics and prebiotics to the consumer. However, not all yogurts are probiotic, neither are they all functional products. There is increasing demand for health-promoting beverages, which is prompting the dairy industry to develop functional probiotic yogurts to meet the demand. However, there seems to be a scarcity of reviews providing critical information on regulatory frameworks in regions of the world, clinical trial outcomes, and methodological approaches for enumerating multiprobiotic strains in yogurt. This review, relating to functional probiotic yogurt, covers the newest information on the topic for the period mostly between 2014 and 2019. Conformance to regulations is paramount and hence, global regulatory frameworks for probiotic yogurt and prebiotic and nonprebiotic ingredients included in yogurt are reviewed. The paper emphasizes the need for convincing clinical trial outcomes that provide the dairy industry with an opportunity to market products with substantiated beneficial claims. The paper also discusses probiotic strains in functional yogurt, which is required to have population levels above the recommended therapeutic minimum during shelf life. The multiprobiotic species added to yogurt may present challenges relating to methodological and analytical approaches needed to determine viability of each strain contained in such yogurt. Hence, the review also presents the pros and cons of the culture-dependent and culture-independent approaches for the enumeration of probiotic cells in yogurt. The review is arguably valuable to the dairy industry, functional food developers, related scientists, and researchers, as well as policy makers.
\end{abstract}

Key words: probiotic yogurt, therapeutic minimum, assessing viability, regulation, clinical trials

Received June 18, 2020.

Accepted August 15, 2020.

*Corresponding author: elna.buys@up.ac.za

\section{FERMENTATION AND BENEFITS OF YOGURT PROCESSING}

Fermentation is a food preservation process as old as mankind and is aimed at extending the shelf life and improving the sensory and nutritional quality of foods and beverages (Marsh et al., 2014; Kamal et al., 2018). Fermentation is a metabolic process that enables the deriving of energy from an organic substrate without involving an exogenous oxidizing agent (Ray and Joshi, 2015). Lactic acid fermentation leads to a food matrix of reduced $\mathrm{pH}$, creating harsh conditions for foodborne pathogens in yogurt and other fermented products (Cutrim et al., 2016; Kamal et al., 2018). Worldwide, fermented foods are linked to potential beneficial effects in the consumer (Marsh et al., 2014).

Organic acid content and rate of acid production affect viscosity and the gelling properties of yogurt, requiring a constant rate of acid production (Hill et al., 2017). Fermenting milk is, inter alia, advantageous due to release of bioactive peptides or bacteriocins (catalyzed by the proteolytic enzymes of the fermenting cultures); lactose content reduction (Moineau-Jean et al., 2019), which benefits lactose-intolerant consumers; and generally an improvement in the food's sensory quality (Bisanz et al., 2014; Ray and Joshi, 2015; MoineauJean et al., 2019).

\section{PROBIOTIC MICROORGANISMS AND POTENTIAL HEALTH BENEFITS}

Probiotic bacteria are live microorganisms that, when administered in adequate amounts, confer a health benefit on the host (Abd El-Gawad et al. 2014; Hill et al., 2014). Yogurt or fermented milk is, reportedly, the most commonly used vehicle for delivering to the consumer probiotic microbial strains generally regarded as safe (GRAS; Bisanz et al., 2014; MoineauJean et al., 2019). Table 1 shows some of the species that are reported to have probiotic potential. Since 1901, when Lactobacillus delbrueckii was named as the first Lactobacillus species, researchers of microbial taxonomy grouped several diverse bacteria (more than 
250 species) under the important genus Lactobacillus even though their relatedness was not so close for some species (Zheng et al., 2020). Recent years of sophisticated DNA sequencing and analysis have enabled a panel of experts to split the genus Lactobacillus into 25 genera including the emended genus Lactobacillus, which includes host-adapted organisms that have been referred to as the L. delbrueckii group; Paralactobacillus; as well as 23 novel genera: Acetilactobacillus, Agrilactobacillus, Amylolactobacillus, Apilactobacillus, Bombilactobacillus, Companilactobacillus, Dellaglioa, Fructilactobacillus, Furfurilactobacillus, Holzapfelia, Lacticaseibacillus, Lactiplantibacillus, Lapidilactobacillus, Latilactobacillus, Lentilactobacillus, Levilactobacillus, Ligilactobacillus, Limosilactobacillus, Liquorilactobacillus, Loigolactobacillus, Paucilactobacillus, Schleiferilactobacillus, and Secundilactobacillus (Zheng et al., 2020). Workers in research institutes and stakeholders in the food industry ought to take note of the current microbial taxonomic changes, some of which are reflected in Table 1, even though previous nomenclature is maintained in the text.

Table 2 shows some of the potential health benefits that may be derived by hosting probiotics that may be delivered to the consumer by yogurt (Arief and Taufik, 2016). Benefits include gut microbial balance and mineral absorption; prevention of constipation; reduction in serum cholesterol, lactose intolerance, and blood pressure (El-Fattah et al., 2016; Zhang et al., 2019); reduction of chances of developing colon cancer (Fijan, 2014; Palomar et al., 2014; Ribeiro et al., 2014; Moineau-Jean et al., 2019); prevention of diarrhea, intestinal infections, and inflammatory bowel syndrome (Muniandy et al., 2016); and stimulation of the immune system (Innocente et al., 2016).

Yogurt and other fermented milk products accumulate bioactive peptides that have antioxidant activity (Muniandy et al., 2016). The bioactive peptides released in milk by selected probiotic strains inhibit angiotensin-converting enzyme (ACE; Zhou et al., 2019). Inhibiting ACE is linked to reduced blood pressure or hypertension (Zhou et al., 2019). The bioactive peptides inhibit ACE by blocking the conversion of inactive angiotensin I to the vasoconstrictor angiotensin II, which in turn results in an increase in the vasodilator bradykinin, leading to a reduction in blood pressure (El-Fattah et al., 2018). Probiotic milk fermented by Lactobacillus helveticus $\mathrm{H} 9$ was shown to have antihypertensive peptides and was shown to inhibit ACE (Chen et al., 2014), which could contribute to clinical reduction of challenges linked to high blood pressure (El-Fattah et al., 2016; Hussain et al., 2018). Inhibition of ACE depends on probiotic inoculum size and $7 \log _{10} \mathrm{cfu} / \mathrm{mL}$ led to an ACE inhibitory activity

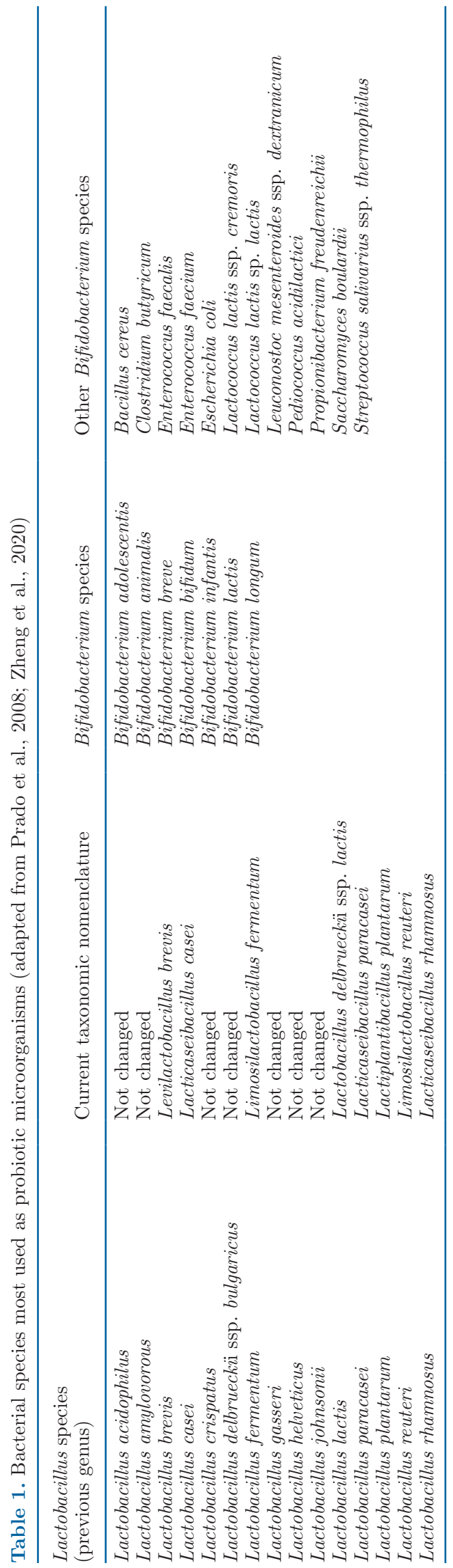




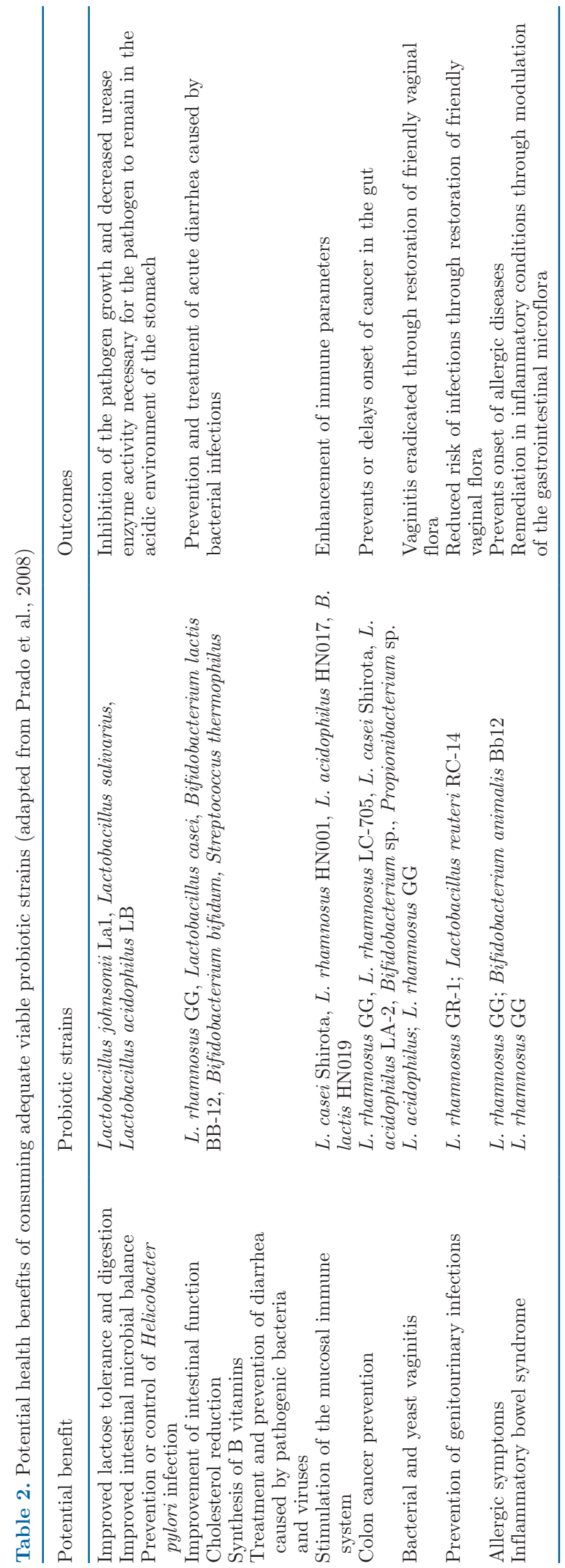

of $70 \%$ compared with the $30 \%$ of the control milk sample (Zhou et al., 2019).

Cancer, a worldwide health challenge, is described as the growth and spreading of uncontrolled abnormal cells in the body (Sah et al., 2015). As cancerous cells become more resistant to chemotherapy (Sah et al., 2015), alternative treatments are needed, and bioactive peptides may induce apoptosis of malignant somatic cells and inhibition of pathogenic bacterial cells (Elfahri et al., 2015; Sah et al., 2015). The mechanism relates to the negatively charged cancer and bacterial cells getting bound by the positively charged peptides from the probiotic milk (Elfahri et al., 2015; Sah et al., 2015). Bioactive peptides can rupture the membranes of the negatively charged cells resulting in their demise (Sah et al., 2015).

\section{Selection of Health-Promoting Probiotic Strains for Inclusion in Yogurt}

The initial step in probiotic product development is strain selection (Tripathi and Giri, 2014). Strains including Lactobacillus rhamnosus GR-1, and Lactobacillus reuteri $\mathrm{RC}-14$ can retain viability in yogurt during shelf life of the product (Hekmat et al., 2009; Aryana and Olson, 2017). It is crucial to optimize growth conditions for selected probiotic strains due to possible nonsynergistic interaction between yogurt cultures and probiotic strains (Bisanz et al., 2014). Probiotic strains need to be evaluated as stipulated in Table 3.

Consumers' liking for probiotic functional foods lies more in the claimed health benefits than in the nutritional claims, and the former is linked to viability of the probiotic strains (Verbeke et al., 2009; Marsh et al., 2014). Selection criteria for probiotic strains include safety, as well as technological, sensory, and functional properties of the strains (Innocente et al., 2016; Kamal et al., 2018).

In terms of safety, strains of Lactobacillus and Bifidobacterium have GRAS status and are the most studied genera included in foods (Marsh et al., 2014; Ribeiro et al., 2014; Tripathi and Giri, 2014; Aryana and Olson, 2017). In Sweden and Finland, L. rhamnosus LGG is consumed in large amounts without resultant Lactobacillus bacteremia being reported. Neither was any negative effect found when LGG was fed to pregnant women and persons with human immunodeficiency virus (HIV; Hill et al., 2017). Enterococcus, Lactococcus, Saccharomyces, and Pediococcus genera also are regarded as harboring potential probiotic species (Tripathi and Giri, 2014).

Appropriate probiotic cultures enable the processing of fermented products with the desired sensory attributes (texture, aroma, and flavor) because consumers' 
Table 3. Guidelines for evaluation of probiotics (adapted from Hill et al., 2017)

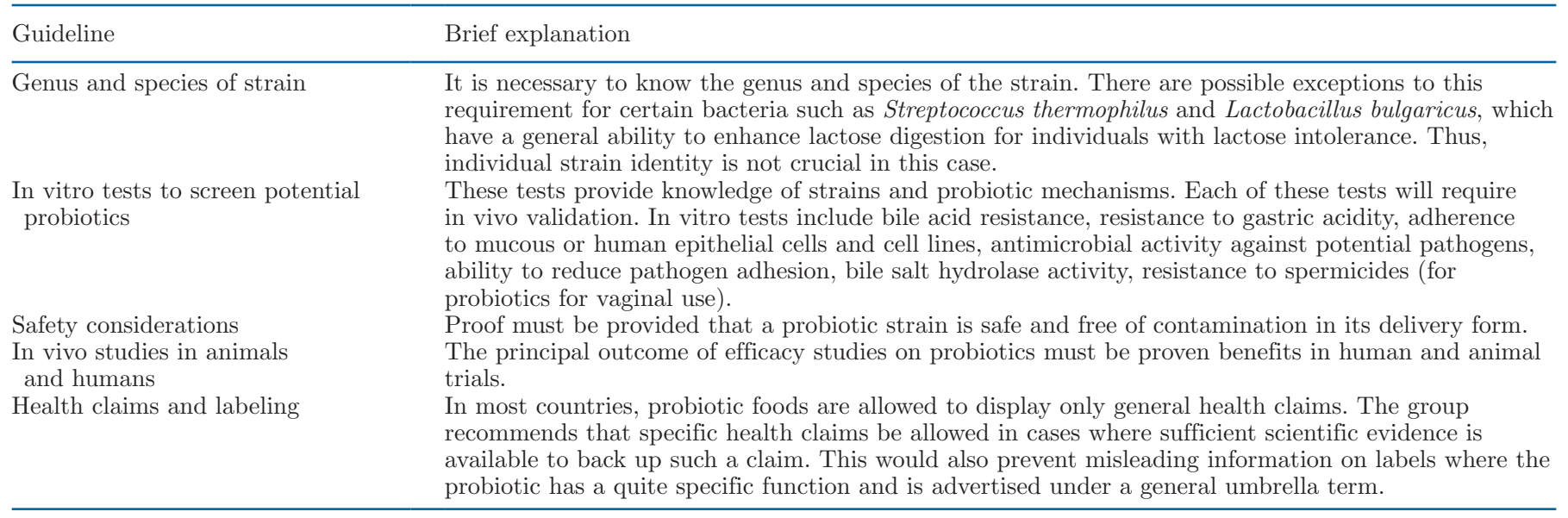

detection of sourness or bitterness, and off-flavors may influence the acceptance of the beverage (Marsh et al., 2014). Microencapsulated probiotic cells added to yogurt fermented by yogurt cultures may circumvent possible negative sensory attributes due to a probiotic strain (Ribeiro et al., 2014; Amakiri et al., 2015; Eratte et al., 2018).

In terms of functional properties, species such as Lactobacillus acidophilus that are included in dairy products may contribute to a reduction in serum cholesterol, relief from lactose intolerance, and reduction of chances of developing colon cancer (Zhang et al., 2019). Antimicrobial metabolites (acids and bacteriocins) may contribute to biopreservation (inhibition of pathogens) and confer health benefits (Abd El-Gawad et al., 2014; Marsh et al., 2014; Kamal et al., 2018).

Technologically, probiotic inclusion in yogurt is challenging due to strain-specific viability difficulties during refrigerated storage (low $\mathrm{pH}$ and high acidity) and slow probiotic growth in milk due to inadequate proteolytic enzymes (Marafon et al., 2011; Innocente et al., 2016). Interaction between microbial cultures in the product can affect the growth of the yogurt starter cultures and probiotic viability (Terpou et al., 2017). In particular, Streptococcus thermophilus (a starter culture) is reported to weaken the health-promoting potential of probiotic strains (Terpou et al., 2017). The detrimental effect on probiotic survival is also linked to sensitivity to ingredients added to yogurt and the conditions of processing and storage, including acidity, $\mathrm{pH}$, temperature, oxygen levels, and other factors that affect survival of beneficial bacteria (Jungersen et al., 2014; Terpou et al., 2017).

There is a plethora of studies that report positive results relating to growth and survival of probiotic strains in yogurt. In a study by Illupapalayam et al. (2014), all yogurts spiced with cardamom, nutmeg, or cinnamon had probiotic strain LA5 counts in the range $5 \times 10^{7}$ to $10^{8} \mathrm{cfu} / \mathrm{g}$, whereas samples containing probiotic Bifidobacterium strain Bb12 had counts in the range of $10^{6}$ to $10^{7} \mathrm{cfu} / \mathrm{g}$ after $28 \mathrm{~d}$ of shelf life. In a study by Innocente et al. (2016), the counts of the starter culture and probiotic L. rhamnosus DSA LR1 were maintained at above $7 \log _{10} \mathrm{cfu} / \mathrm{mL}$ after $20 \mathrm{~d}$ of storage at $4^{\circ} \mathrm{C}$. This was confirmed by the plating technique for lactic acid bacteria and PCR-denaturing gradient gel electrophoresis molecular technique (Innocente et al., 2016). The nonencapsulated and encapsulated probiotic strain L. acidophilus LA5 in yogurt had respective viability of $1.58 \times 10^{7} \mathrm{cfu} / \mathrm{g}$ and $1.12 \times$ $10^{7} \mathrm{cfu} / \mathrm{g}$ after $35 \mathrm{~d}$ of refrigerated storage (Ribeiro et al., 2014). The presence of the probiotic strain did not affect the viability of the starter cultures, as the cell counts of L. bulgaricus and S. thermophilus were 7.99 $\times 10^{6} \mathrm{cfu} / \mathrm{g}$ and $4.5 \times 10^{8} \mathrm{cfu} / \mathrm{g}$, respectively, in the yogurt containing the nonencapsulated probiotic strain and $1.91 \times 10^{6} \mathrm{cfu} / \mathrm{g}$ and $6.92 \times 10^{8} \mathrm{cfu} / \mathrm{g}$ in the yogurt containing the encapsulated probiotic strain LA5 (Ribeiro et al., 2014). Lactobacilli such as L. helveticus strains (R0052, LBK-16H, H9, CP790) are reported as being used as fermentation starter cultures or food additives (Zhou et al., 2019) possibly due to their ability to maintain population levels above the recommended therapeutic minimum. Essentially, the foregoing studies' findings imply that viability or fate of probiotics in yogurt containing yogurt cultures is species and strain dependent in addition to factors such as additives or yogurt-recipe ingredients, processing conditions, time of storage, methods of enumerating probiotic cells, and expertise of the quality control workers in relation to employing selective and differential media (in the case of pour plate approaches).

Lactobacillus rhamnosus is one of the most studied and used species in probiotic foods and supplements 
(Kamal et al., 2018). Arguably, L. rhamnosus LGG is the most thoroughly studied probiotic strain (Segers and Lebeer, 2014; Hill et al., 2017; Kamal et al., 2018). Selection of strain LGG relates to its reported probiotic characteristics (bile resistance, resistance to gastric acid), ability to colonize the gut, inhibition of indicator pathogens, and stimulation of the immune system (Kamal et al., 2018). The L rhamnosus strains produce lactic acid in relatively large amounts (Beristain-Bauza et al., 2016). Hence, optimal growth of L. rhamnosus is influenced by the $\mathrm{pH}$ level, as its growth at $\mathrm{pH} 4.2$ is considerably better than at pH 5 (Mpofu et al., 2014, 2016; Kamal et al., 2018). When yogurt is used as the delivery vessel for $L$. rhamnosus, the viability of the probiotic is not affected as much as for other species (such as Bifidobacterium longum, Bifidobacterium bifidum, Lactobacillus casei, and L. acidophilus) that are more variably subdued by yogurt's low pH (Kamal et al., 2018). However, among the Bifidobacterium strains, Bifidobacterium animalis ssp. lactis BB-12 (the most documented) is technologically tolerant to oxygen, proliferates in milk through lactose metabolism (unlike most lactobacilli), maintains high viability during storage, and exhibits appreciable probiotic properties and health benefits, which reasonably enables manufacturers to subject it to worldwide marketing using yogurt and other dairy products as delivery vessels to the consumer (Masco et al., 2004; Jungersen et al., 2014). Probiotics selected for addition into yogurt and other beverages need to be health promoting, technologically suitable, and compatible with yogurt cultures (Bisanz et al., 2014; Marsh et al., 2014; Tripathi and Giri, 2014; Innocente et al., 2016).

\section{Reasons for Labeling Some Bacterial Species as Nonprobiotic}

Procedures and regulations stipulate the use of both S. thermophilus and L. bulgaricus as starter cultures in the production of yogurt due to their symbiotic relationship (Aryana and Olson, 2017; Hill et al., 2017). Yogurt starter cultures, however, may not necessarily be regarded as probiotic because their inability to significantly resist bile and gastric acid conditions inhibits their viability and survival in the gastrointestinal tract. Nonetheless, yogurt cultures are able to improve lactose intolerance due to lactose fermentation in the milk (Hekmat et al., 2009). Yogurt cultures have also been shown to help strengthen the immune defense and reduce or prevent diarrhea (Chandan et al., 2017). In relation to the aforementioned potential benefits, yogurt cultures could possibly be regarded as having probiotic characteristics (Chandan et al., 2017).
There are, however, conflicting reports that refute the probiotic potential of yogurt cultures, albeit they improve lactose digestion. It is important to note that yogurt cultures retaining confirmed high viability in the human gastrointestinal tract may not necessarily impart health benefits to the host (Chandan et al., 2017). There needs to be an associated clinical effect as evidenced in clinical trials. Refuting the probiotic potential of yogurt cultures relates to some workers asserting that the yogurt starter cultures could not metabolize phenolic compounds in green tea, such as catechin, epigallocatechin gallate, epigallocatechin, catechin gallate, and epicatechin gallate (Muniandy et al., 2016). This compared with the fact that some probiotic lactobacilli have been reported to metabolize phenolic compounds in food (Muniandy et al., 2016).

\section{REGULATIONS AND RECOMMENDATIONS RELATING TO PROBIOTIC FOOD PREPARATIONS}

\section{Safety of Probiotic Strains with the Potential for Inclusion in Yogurt}

Products regarded as probiotic may contain a single strain or multistrains (several strains of the same species or genus) of probiotic bacteria (de Simone, 2019). According to Turkmen et al. (2019), Lactobacillus and Bifidobacterium species are arguably the most studied and have appeared in more than 1,265 and 625 clinical trials, respectively, since the 1950s. Given that most of the probiotic strains are obtained from fermented beverages that had been consumed for a historical period of time, such strains are GRAS by the European Food Safety Authority (EFSA) and the US Food and Drug Administration (FDA; de Simone, 2019; Kothari et al., 2019). Central to safety evaluation of potential probiotic strains is the confirmation of taxonomic classification at species level, but also the whole-genome sequencing of the specific strain to analyze for antibiotic resistance genes with the need to establish whether observed resistance is intrinsic (nontransferable) or acquired (transferable; Saarela, 2018; Sotoudegan et al., 2019). Enzymatic activities of potential probiotic strains, such as bile salt hydrolase (BSH) activity and hemolytic activity, also need to be assessed as stipulated by Saarela (2018). Moderate BSH may lower cholesterol levels in the blood by hydrolyzing the bile salts; however, hyper BSH activity was reported to potentially impair lipid metabolism and contribute to the accumulation of gall stones (Bustos et al., 2012; Kothari et al., 2019).

Furthermore, in conducting safety evaluations, the following need to be considered: probiotic physiological functions, recipients' health status, mode of adminis- 
tering the probiotics (orally or vaginally), the form of administration (liquid or powder), and the probiotic strains involved (de Simone, 2019; Kothari et al., 2019). There are 2 aspects linked to the safety of probiotics: the potential adverse effect of the probiotic strain and the potential infection or effects of toxins produced by contaminants in the probiotic beverage/foodstuff (de Simone, 2019; Sotoudegan et al., 2019). Nonetheless, only a few reports have indicated cases of sepsis attributed to Lactobacillus strains and fatality linked to gastrointestinal mucormycosis of preterm infants associated with contamination of the beverage with mycotoxic molds (Doern et al., 2014; de Simone, 2019; Kothari et al., 2019; Sotoudegan et al., 2019). Increased mortality risk was also reported in vulnerable patients suffering from acute pancreatitis following administration of multispecies probiotic products (de Simone, 2019).

It is therefore recommended that safety be taken seriously when administering probiotics to vulnerable groups (preterm neonates, infants, the elderly, hospitalized patients, or immunocompromised individuals; Sotoudegan et al., 2019), particularly in cases of HIV and in persons with diseased liver, inflammatory bowel syndrome, injured mucosa, or immune dysregulation (de Simone, 2019; Kothari et al., 2019). Saccharomyces boulardii incorporated in probiotic products and administered to patients in some hospitals was linked to fungemia in very ill individuals or immunocompromised hospitalized persons (Santino et al., 2014; Kara et al., 2018; Martin et al., 2017; de Simone, 2019; Kothari et al., 2019). De Simone (2019) on the other hand reported that in HIV-infected persons receiving antiretroviral treatment and administered with probiotic supplements did not experience any side effects. The patients in fact exhibited immuno-beneficial effects and improved gut epithelial barrier function. It would be more pragmatic, however, to assume that this outcome is not necessarily always applicable. It is important to note that in most of the cases in which probiotic strains were implicated in infections, the individuals involved were either immunocompromised or had serious underlying health challenges (Santino et al., 2014; Kara et al., 2018; Martin et al., 2017).

\section{Probiotic Efficacy and Clinical Trials}

Enhancing probiotic numbers in the gut of the host is not sufficient to expect approval of a health claim (Marsh et al., 2014). Evidence of efficacy or clinical outcomes must be submitted to regulatory authorities. Reports indicate that probiotic health claims are based mostly on in vitro and in vivo animal models and less on clinical trials (Turkmen et al., 2019). It is better, however, to not extrapolate in vitro and animal in vivo assessment outcomes to human outcomes. Probiotic efficacy needs to be investigated, confirmed, and approved in accordance with well-designed human clinical trials (Marsh et al., 2014; Turkmen et al., 2019). Although this is expected to be the case, there is a shortage of clinical trials to assess the effectivity of probiotic dairy products (Turkmen et al., 2019). Several workers observed that there are only a few reports relating to clinical trials, and those that are available may not be fully randomized, double-blind, placebo-controlled trials (Bogović Matijašić et al., 2016). Generally, the number of human clinical trials conducted thus far is not big enough, and those conducted may not be large enough to have scientifically acceptable statistical significance (Turkmen et al., 2019). A good number of clinical trials are conducted using healthy participants, which makes confirmation of therapeutic effects difficult to infer (Bogović Matijašić et al., 2016). Hence, one of the challenges relating to confirming a health claim is the need to conduct randomized, double-blind, placebo-controlled clinical trials, which is an expensive (and time-consuming) exercise, before marketing of the functional product (Marsh et al., 2014).

The EFSA has rejected all the health claims that were submitted by manufacturers due to lack of validity, inadequate characterization, unconvincing beneficial effect on nutrition and physiological improvement, lack of placebo and randomization in clinical trials, and absence of quality and scientific design for the trials (Turkmen et al., 2019). In the United States, a clinical guide is available that provides important information relating to practical outcomes of clinical trials, and it gets updated regularly at http://usprobioticguide.com (Turkmen et al., 2019). It is recommended to conduct 3 levels of clinical assessment: (1) randomized clinical trials, (2) controlled cohort or case control trials, and (3) systematic analysis and expert reports (Turkmen et al., 2019).

\section{Recommendations for Probiotic Preparations by the Regulatory Bodies}

According to the definition provided by the Food and Agriculture Organization of the United Nations and World Health Organization (FAO/WHO, 2002) and modified in 2013 by an expert panel (Hill et al., 2014), the microorganisms incorporated into yogurt should be in abundance and of high viability (WHO/FAO, 2011; Hill et al., 2017).

The use of the word probiotic on product labels is restricted in some regions of the world. In the European Union (EU), using the word probiotic is understood to be a health claim, and its inclusion on the label 
requires health claim approval by the EFSA (Marsh et al., 2014). The EFSA does not permit the use of the word probiotic on the label of products containing GRAS strains (de Simone, 2019). This is in contrast to the FDA stance, which does allow the use of the term probiotic (de Simone, 2019), and several strains are considered safe for human intake by the FDA. However, in Canada and the United States, manufacturers need to provide clinical evidence for the probiotic strain in the product, and if the product contains multistrains, the clinical evidence should be for the entire combination and not an extrapolation of a part of it (Turkmen et al., 2019). In Canada, the regulation requires the dairy product labeled as yogurt to declare the presence of the 2 characterized cultures ( $L$. bulgaricus and S. thermophilus; Chandan et al., 2017). The viability of a probiotic strain declared in a beverage should be a minimum level of $1.0 \times 10^{9}$ cfu per stated serving size of food maintained throughout product shelf life (https://www.canada.ca/en/health-canada/services/ food-nutrition/food-labelling/health-claims/accepted -claims-about-nature-probiotic-microorganisms-food .html).

Japan's Ministry of Health, Welfare and Labor formed the food for specified health uses (FOSHU) guidelines for functional foods in 1991 (Foligne et al., 2013; Kumar et al., 2015; Iwatani and Yamamoto, 2019). Through use of FOSHU guidelines, foods and beverages that contain active ingredients bearing scientifically substantiated and confirmed proof of health claims are approved to bear the FOSHU tag on the product label (Foligne et al., 2013; Kumar et al., 2015). Unlike EFSA regulation, in Japan as long as the active ingredient was approved by the government, the label of the product in which the active ingredient is contained can bear the FOSHU tag (Foligne et al., 2013; Kumar et al., 2015). The EFSA requires a clinical trial to be conducted using the product containing the active ingredient, not the identity of the latter alone (Foligne et al., 2013).

India does not seem to have an established regulatory authority for probiotic products (Foligne et al., 2013). Reportedly, India's Council of Medical Research did embark on the compilation of guidelines for assessing probiotic strains in products to infer potential efficacy of claims (Foligne et al., 2013).

The Chinese State Food and Drug Administration stipulates requirements of human clinical trials and interventions similar to those of EFSA in the EU. However, China accepts animal model-based substantiated health claims if human clinical trial outcomes are still outstanding (Foligne et al., 2013).

The Brazilian legislation with regard to yogurt requires the total viability count for lactic acid bacteria in traditional yogurt to be more than $7 \log _{10} \mathrm{cfu} / \mathrm{mL}$ throughout the shelf life period (Ribeiro et al., 2014). In Australia, ABT cultures are permitted in yogurt, in which case the main organisms are L. acidophilus, Bifidobacterium, and S. thermophilus (Chandan et al., 2017).

With regard to composition, the FDA in the United States also requires cultured milk to contain at least $3.25 \%$ milk fat, $8.25 \%$ milk solids-nonfat, and a titratable acidity of $0.5 \%$ expressed as lactic acid (Kilara, 2017). The regulation also allows fortification with vitamins A and D (Kilara, 2017). The US standards require the production of yogurt with yogurt starter cultures, and probiotic cultures may be added to yogurt (Chandan et al., 2017). The US yogurt production regulations (US FDA, 2019) describe yogurt as a dairy product processed using fermenting yogurt cultures (L. delbrueckii ssp. bulgaricus and S. thermophilus), although other lactic acid bacteria may also be incorporated into yogurt (Kilara, 2017).

In South Africa, there are 2 regulations that relate to yogurt standards. The first regulation is provided by the Department of Health (DOH). According to the $\mathrm{DOH}$, the use of the word probiotic on the yogurt product label is not permitted by the country's amended regulations relating to the labeling and advertising of foods [Foods, Cosmetics and Disinfectants Act, 1972 (Act No. 54 of 1972: R.429); South Africa Department of Health, 1972]. A functional claim linked to microbiological content in yogurt can only be made if the yogurt culture comprises of $L$. delbrueckii ssp. bulgaricus and $S$. thermophilus. The regulation further states that the wording for the functional claim shall be as follows: "yogurt cultures improve lactose digestion in individuals who have difficulty in digesting lactose (milk sugar)," as long as the yogurt culture population level in the dairy yogurt is not less than $10^{8} \mathrm{cfu} / \mathrm{g}$ (South Africa Department of Health, 1972).

The second regulation is by South Africa's Department of Agriculture (DOA); this regulation (R.260, ACT No. 119 of 1990; South Africa Department of Agriculture, 2015) somewhat contradicts the DOH's regulation. According to DOA's regulation (R.260), which is an amendment of South Africa's Agricultural Product Standards Act, 1990 (ACT No. 119 of 1990; South Africa Department of Agriculture, 2015), yogurt culture is defined as a culture consisting of $L$. delbrueckii ssp. bulgaricus and S. thermophilus or another similar culture used for the manufacture of the primary dairy product known as yogurt. The standard for yogurt and drinking yogurt (South Africa Department of Agriculture, 2015) requires yogurt and drinking yogurt to contain at least $10^{7} \mathrm{cfu} / \mathrm{g}$ of yogurt culture in a final product. The same standard also allows the addition of 
other specific microorganisms in yogurt (to supplement the yogurt culture), in which case, their presence in the product should be claimed on the label and their viability should be at least $10^{7} \mathrm{cfu} / \mathrm{mL}$ for each specific microorganism (South Africa Department of Agriculture, 2015). Although the taxonomic nomenclature for the additional specific microorganisms may be included on the yogurt product label, they are not permitted to be stated as probiotic.

To summarize South Africa's regulations, R.429 does not permit the use of the word probiotic on the product label. The amended Agricultural Product Standards Act, 1990 (R.260, ACT No. 119 of 1990) permits the incorporation of specific probiotic strains in yogurt products as long as only their taxonomic nomenclature and minimum population levels are appended on the product label. Although DOH's regulation requires $10^{8} \mathrm{cfu} / \mathrm{g}$, the DOA's regulation stipulates $10^{7} \mathrm{cfu} / \mathrm{g}$ for every species claimed on the yogurt product label. These contradictions require attention by the respective South African government departments.

\section{PREBIOTIC AND NONPREBIOTIC FUNCTIONAL INGREDIENTS IN PROBIOTIC YOGURT}

\section{Prebiotic Ingredients with Potential for Inclusion in Yogurt}

The definition of a prebiotic has been modified to a substrate that is selectively utilized by host microorganisms conferring a health benefit. Substances such as polyphenols and polyunsaturated fatty acids converted to respective conjugated fatty acids might fit the updated definition, assuming convincing weight of evidence in the target host (Gibson et al., 2017). Generally, inulin, galactooligosaccharides, fructooligosaccharides, oligofructose, resistant starch, lactulose, and polydextrose are the major prebiotic ingredients that may be added to dairy products to stimulate growth or proliferation of fermenting beneficial bacteria during fermentation, refrigerated storage, and in the gut (Marsh et al., 2014; Mousavi et al., 2019; Sah et al., 2015).

Specific nuts, grains, and fruits, reported by several workers, may be added to yogurt as prebiotics but can potentially affect physicochemical parameters, texture, and rheology, and if not selected carefully, may negatively change the consumer acceptability of the yogurt during its refrigerated shelf life (Januário et al., 2017; Mousavi et al., 2019; Sah et al., 2016; Terpou et al., 2017; Turkmen et al., 2019). It may be noted that growth and viability of specific probiotic strains in yogurt depend on the type and concentration of the prebiotic ingredient added to the yogurt (Abd El-Gawad et al., 2014; Baruzzi et al., 2017; Terpou et al., 2017; Turkmen et al., 2019; Zhang et al., 2019).

\section{Nonprebiotic Functional Ingredients with Potential for Inclusion in Yogurt}

Historically, yogurt consumption was linked to the belief that it improves health and well-being (Aryana and Olson, 2017; Turkmen et al., 2019). Yogurt's perceived potential health benefits to the consumer has led to the food industry's desire to innovate and market new yogurt products containing added so-called functional nonprebiotic ingredients (Marsh et al., 2014). Apart from proposing the current definition of prebiotic, Bindels et al. (2015) further define prebiotic effect as the beneficial physiological outcome that arises from the modulation of the composition or activity of the gut microbiota through the metabolization of a nondigestible compound. Prebiotic effects may be realized from the nonprebiotic functional ingredients that may include probiotics, minerals, vitamins, fish oil, fibers, phytosterols (or stanols), omega-3 fatty acids, polyphenols, isoflavones, bioactive compounds, and hydrolyzed whey protein (Champagne et al., 2018; Fazilah et al., 2018; Turkmen et al., 2019). Phytosterols (a phytonutrient) has cholesterol-reducing ability; isoflavones are strong antioxidants; CLA is anti-atherogenic, can depress total cholesterol, and inhibits the growth of some human cancer cell lines, as well as modulate the immune system and promote growth of the consumer (Faihst et al., 2017; Marsh et al., 2014). However, some nonprebiotic functional ingredients have technological challenges. For instance, omega-3 fatty acids are slightly fishy and sensitive to heat, air, and light, and phytosterols and isoflavones are hydrophobic, which makes them rather difficult to add to nonfat food matrices (Marsh et al., 2014).

\section{METHODS FOR ASSESSING VIABILITY OF CELLS AND BACTERIAL COUNTS OF MIXED PROBIOTIC STRAINS IN YOGURT AND FOR CHARACTERIZING THE COMPONENT STRAINS}

Probiotic beverages need to conform to safety, quality, and functional requirements (Davis, 2014). First and foremost, the probiotic organisms in the product should have viable counts above the recommended therapeutic minimum stated on the label (Davis, 2014; Vinderola et al., 2019). It is important to investigate the viability by employing suitable methods, as there have been reports of nonconformance to regulatory requirements (Davis, 2014). The culture-dependent approach is one of the ways by which probiotic population levels may be enumerated. 


\section{Use of Culture-Dependent Techniques to Investigate Bacterial Counts and Cell Viability of Probiotic Bacteria in Yogurt}

The period between fermentation and consumption may subject the probiotic cells to stress rendering them less functional albeit still viable (Davis, 2014; Hill et al., 2017; Vinderola et al., 2019). The implication is that although the plate count method may reflect the magnitude of the population levels, it may not indicate the proportion of stressed cells present (Bogović Matijašić et al., 2016; Hill et al., 2017). There is, nevertheless, potential for the viable but nonculturable (VBNC) or stressed probiotic cells to offer health benefits to the host (Rodríguez-Nogales et al., 2015; Sakar, 2018). Culture-dependent techniques for assessing probiotic viability have challenges such as being laborious and time intensive, with an extended incubation period of 72 to $96 \mathrm{~h}$ in some cases (Vinderola et al., 2019). The other challenge during the enumeration of probiotics in yogurt is that there are only a few standardized differential or selective plate count methods. These include International Organization for Standardization (ISO) methods such as ISO 20128 (ISO, 2002) for $L$. acidophilus and ISO 29981 for Bifidobacterium (Davis, 2014; Vinderola et al., 2019). This is linked to the fact that most of the probiotics incorporated into yogurt are closely related to the starter cultures that also belong to the lactic acid bacteria (LAB) group and have almost similar cultural and metabolic requirements (Davis, 2014; Hill et al., 2017; Vinderola et al., 2019). This complicates the need to find suitable media to selectively grow and differentiate closely related probiotic strains present in combination in the same product and at the same time inhibit the yogurt starter cultures (Davis, 2014; Hill et al., 2017; Vinderola et al., 2019). On the other hand, the starter cultures can potentially outgrow the probiotic strains. Therefore, the plate count technique, which is a culture-dependent method, has to be employed sensibly, using the right media and conditions during the enumeration of probiotics included in yogurt. Table 4 presents a summary of the selective media and conditions used for the enumeration of probiotic strains in commercial yogurt. The probiotics belonging to the genus Lactobacillus can be enumerated on De Man, Rogosa and Sharpe (MRS) medium whereas $S$. thermophilus and L. bulgaricus, which make up the main yogurt cultures, can be enumerated on M17 medium at a pH of 6.8 (Aryana and Olson, 2017). As shown in Table 4, a range of additives can be added to these media to render them more selective. It appears, from Table 4, that there is a need for the amount of added ingredients and conditions of analysis to be standardized.
It was reported that MRS agar at $\mathrm{pH} 5.2$ or clostridial agar at $\mathrm{pH} 5.3$ can select for the growth of $L$. bulgaricus (white, rough, and irregular colonies that are $1.0 \mathrm{~mm}$ in diameter) just as $S$. thermophilus agar can select for S. thermophilus colonies (round, yellowish, and 0.1 to $0.5 \mathrm{~mm}$ in diameter) (Aryana and Olson, 2017). Culture-dependent approaches, however, are not without challenges. Although selective media or set of techniques to enumerate some Lactobacillus probiotic strains is available, it may not be applicable to all strains of the same species (Davis, 2014; Vinderola et al., 2019). There are almost no differential media for enumerating and differentiating species belonging to the genus Bifidobacterium (Davis, 2014; Vinderola et al., 2019), which complicates content claims of more than one species in a food beverage. The use of selective differential media, to some extent, relies on subjective decisions that require tried and tested skills to provide unquestionable conclusions relating to cell viability. Fortunately, there are developments and advances in the field of culture-dependent approaches for the enumeration of probiotic strains in food products. Further reading about mupirocin-based media for possible selective enumeration of bifidobacteria is recommended in the following references (Rada and Koc, 2000; Miranda et al., 2014; Vlkova et al., 2015).

\section{Flow Cytometry in the Enumeration of Probiotic Cells in Yogurt}

Flow cytometry (FC) is one of the cell-sorting quantitative methods. It allows simultaneous evaluation of the physicochemical characteristics of cells or particles (Davis, 2014; Raymond and Champagne, 2015; Wilkinson, 2018). This method employs the application of fluorescent dyes to cell components, which then assists with identifying the physiological characteristics of live cells, such as membrane integrity, cytoplasmic $\mathrm{pH}$, intracellular enzyme activity, and membrane potential, which when combined reflect the degree of viability (Davis, 2014; Raymond and Champagne, 2015; Wilkinson, 2018). Investigators may use FC to enumerate cells of probiotics in food products and detect contaminants (Raymond and Champagne, 2015). Flow cytometry was successfully used to enumerate total cells (FCT) and viable cells (FCV) of L. rhamnosus R0011 in chocolate. Flow cytometry could be used to establish dead cells by differentiating between FCT and FCV counts; the FCV was close to double the counts obtained in the form of colony-forming units (Raymond and Champagne, 2015). A FC-based species-specific analytical method that employed a polyclonal antibody against the target species enabled rapid enumeration of Bifidobacterium lactis in 4 probiotic dairy products in $2 \mathrm{~h}$ compared 


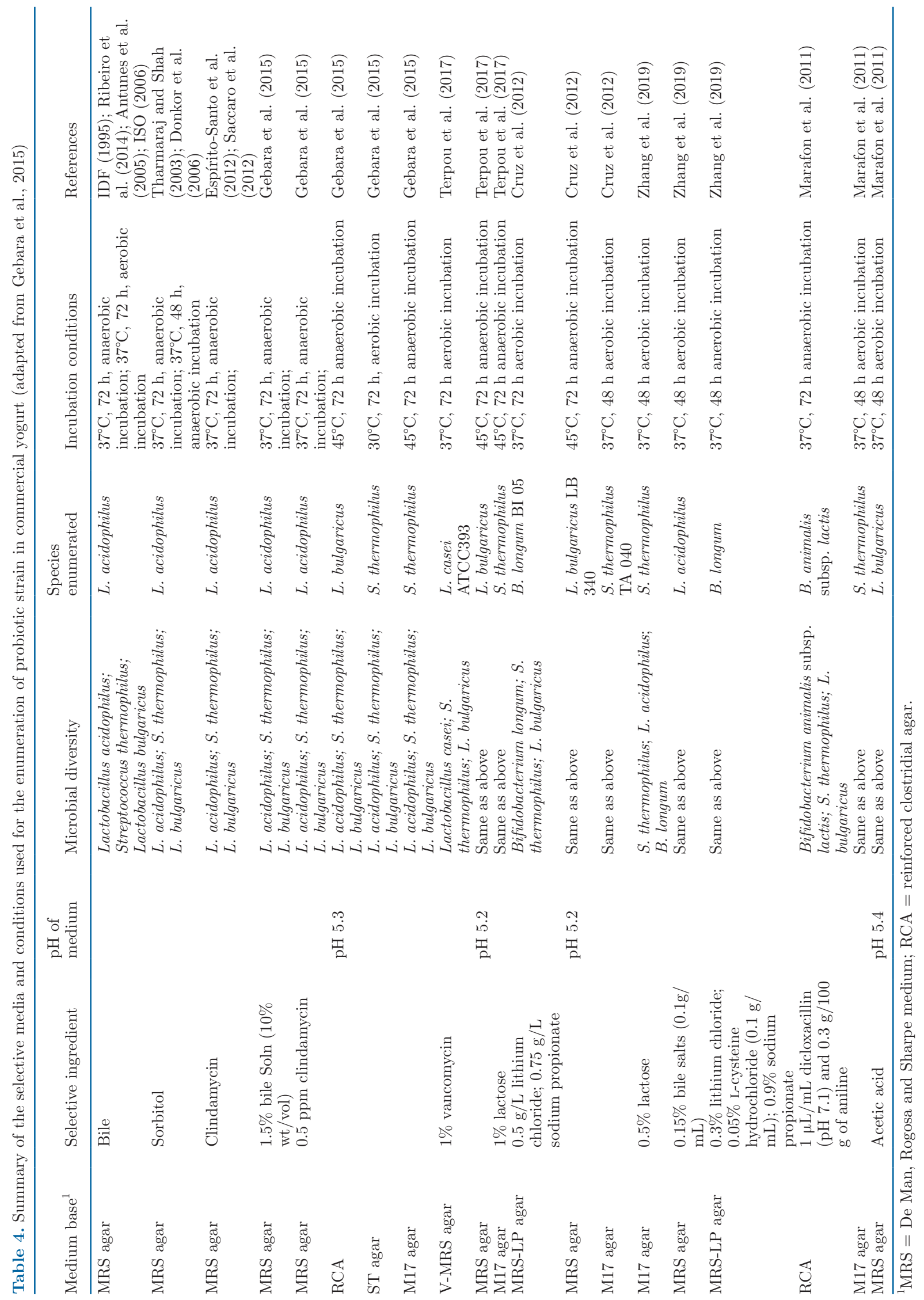


with $72 \mathrm{~h}$ by the ISO standard plate method (Geng et al., 2018). The difficulty with employing FC in enumerating microbial cells in yogurt and other foods relates to the presence of food particles, which can potentially affect the analyses (Raymond and Champagne, 2015). The FC needs careful selection of viability-staining dyes and specific antibody labeling to distinguish probiotic cells from the starter culture cells in yogurt (Wilkinson, 2018).

\section{Culture-Independent (Molecular) Approaches for Investigating Viable Probiotic Cells in Yogurt}

Enumeration of Probiotic Strains Based on $P C R$. These approaches employ the PCR, reverse transcriptase PCR (RT-PCR), and real-time quantitative PCR (RT-qPCR or qPCR). The PCR technique may be used to confirm probiotic viability with the assumption that only DNA of good integrity from nondamaged viable cells gets amplified (Davis, 2014; Shao et al., 2016). It may be noted, however, that good integrity DNA may not imply cell viability (Davis, 2014; Laidlaw, et al., 2019).

The RT-PCR is a variant of PCR that allows a sequence to be amplified severally through RNA transcription to form DNA enabled by the reverse transcriptase enzyme (Davis, 2014). In this case, the probiotic cell viability assumption is based on the fact that the mRNA marker is of very brief half-life and hence, for dead cells, transcription would not happen, and no targetedsequence amplification would be observed (Davis, 2014; Shao et al., 2016). Successful mRNA transcription may better imply cell viability, however, ribosomal RNA (rRNA) can also confirm cell viability (Davis, 2014; Laidlaw, et al., 2019).

The RT-qPCR or qPCR technique entails DNA amplification that employs fluorescent reporter dye to enable amplification, coupled with detection steps of the PCR reaction at the same time in a single-tube format (Davis, 2014). This qPCR technique enables quantification of microbes in the sample through measurement of abundance of the target DNA sequence in the DNA template from a food sample (Davis, 2014; Laidlaw, et al., 2019). The qPCR method has the difficulty of distinguishing between DNA from live and dead cells in yogurt products (Laidlaw, et al., 2019). Because health claims are linked to probiotic strain viability, limitations of the culture-dependent approach may be coupled with molecular techniques to retrieve additional information.

The Use of Ethidium Monoazide-PCR and Propidium Monoazide-PCR. These 2 techniques tend to limit detection to viable cells and hence may be termed viability PCR (vPCR; Davis, 2014). The principle is that although the EMA dye penetrates and intercalates with DNA of cells with injured or compromised membranes, the intact cells remain dye-free (Fittipaldi et al., 2012; Shao et al., 2016; Laidlaw, et al., 2019). Hence, when genomic DNA isolation is done after treating with EMA dye, the dye-linked DNA will not be adequately amplified, although the EMA-free DNA can be sufficiently amplified when qPCR is employed (Davis, 2014; Wilkinson, 2018; Laidlaw et al., 2019). In this case, the presence of cells having compromised membranes but still being metabolically active will result in lower $\log _{10}$ units compared with the control, pointing to a decline in viability (Davis, 2014; Laidlaw et al., 2019). The challenge is the possibility for some intact viable cells to imbibe the EMA dye.

The PMA-PCR technique which employs a similar principle to the EMA-PCR was developed to counter the possibility of intact cells absorbing the Ethidium monoazide dye (Davis, 2014; Shao et al., 2016; Wilkinson, 2018). The propidium monoazide dye may not affect or intercalate living cells; however, at high concentrations, cell viability may decline (Shao et al., 2016). The PMA-PCR technique can illustrate a trend in the death of cells that may be due to processing or storage conditions of the food beverage (Shao et al., 2016). The propidium monoazide can be limited to detecting cells with uncompromised membranes when it is coupled with gel electrophoresis (Fittipaldi et al., 2012; Shao et al., 2016; Laidlaw, et al., 2019). Shao et al. (2016) illustrated that PMA-qPCR could differentiate living cells of $L$. delbrueckii ssp. bulgaricus strain ND02 from the dead cells. The challenge with PMA-PCR arises when handling opaque products such as yogurt, but this can be avoided by applying a trigger instead of light to induce DNA-PMA intercalation or through manipulation of $\mathrm{pH}$ and temperature to change turbidity (Davis, 2014).

Advanced Molecular Approaches for Analyzing Probiotic Preparations. Developing trends are the advanced culture-independent, high-throughput, sequencing-based microbial analyses that are coupled with bioinformatics and metabolomics in investigating diversity and relative microbial abundance within multispecies-containing beverages (Morovic et al., 2016; Patro et al., 2016; Aryana and Olson, 2017). These approaches are employed to determine microbial diversity and abundance (respectively, identity and viability of species) in probiotic beverages and the human gut and to determine the probiotics' effect on gut microbiota (Veiga et al., 2014; Bogović Matijašić et al., 2016; Patro et al., 2016; Lugli et al., 2019). The next-generation sequencing (NGS) technologies including Illumina and Ion torrent (Thermo Fisher Scientific, Johannesburg, South Africa) are the most applied technologies 
in metagenomics analysis; and the others are Pacific Biosciences (Menlo Park, CA) single-molecule real-time sequencing, 454 pyrosequencing, and SOLiD (Applied Biosystems, Johannesburg, South Africa; Chen et al., 2015). The NGS approaches include 16S rRNA amplicon sequencing, 16S rDNA phylogenetic microarray, and metagenomics sequencing (Bogović Matijašić et al., 2016; Morovic et al., 2016; Lugli et al., 2019).

It is important to note that NGS approaches may not enable accurate quantification of the total viable probiotic population or the physiological state of the bacterial cells in the product which is critical for the host to derive potential benefits (Bogović Matijašić et al., 2016; Patro et al., 2016). It is therefore recommended to consider combining molecular high-throughput techniques with quantitative PCR and random amplified polymorphic DNA-PCR analyses for determining cultivable targeted probiotics in product samples (Bogović Matijašić et al., 2016). Although the NGS approaches are quick and can provide results speedily, the cost of the equipment and the bioinformatics and technical expertise needed to employ the right analytical software and to analyze the metagenomics data (to make sound conclusions) may be impediments to employing the more advanced culture-independent technologies.

\section{STUDIES EVALUATING EFFECTIVITY OF PROBIOTIC YOGURT IN TERMS OF HEALTH BENEFITS}

The potential health benefits of probiotics can be assessed in in vitro and in vivo human clinical trials referred to as random, placebo-controlled trials (Aryana and Olson, 2017).

\section{Outcome of Selected In Vitro Investigations}

The health-promoting potential of probiotic strains has led to their consideration and inclusion into dairy products such as yogurt (Iglesias et al., 2017). The major antimicrobial activity of probiotics is attributed to release of hydrogen peroxide, organic acids and peptides, or bacteriocins (Beristain-Bauza et al., 2016; Kamal et al., 2018). In a study by Abd El-Gawad et al. (2014), probiotic yogurt and soy yogurt was observed to inhibit Escherichia coli and Staphylococcus aureus during refrigerated storage largely linked to the presence of probiotic strains B. lactis $\mathrm{Bb} 12$ and B. longum $\mathrm{Bb} 46$ in these yogurts. Table 5 presents in vitro investigations of effectivity of probiotics against pathogens.

In a food model, yogurt spiked with individual pathogens (Staphylococcus aureus, E. coli O157:H7, Salmonella typhi, and Yersinia enterocolitica) and cocultured with a $L$. rhamnosus strain, led to the complete elimination or large-scale reduction of the pathogens depending on the time of incubation and initial pathogen count (Kamal et al., 2018). The workers observed that of the 2 and $4 \log _{10} \mathrm{cfu} / \mathrm{mL}$ inoculation levels of the pathogen, the former (lower) count was cleared faster.

Probiotic strains release metabolites such as hydrogen peroxide, organic acids to lower $\mathrm{pH}$, and bacteriocins, which synergistically may inhibit pathogens (Abd ElGawad et al., 2014). Kamal et al. (2018) observed that acidified L. rhamnosus cell-free supernatants (CFS) significantly inhibited all pathogens tested, and because the neutralized CFS also inhibited the pathogens, other factors (peptides or bacteriocins) besides organic acids were reckoned to have inhibitory activity. The bioactive peptides contained in milk proteins can be released by the proteolytic enzymes from the human gut or by probiotic LAB (Elfahri et al., 2015). The L. helveticus strains in skim milk released bioactive peptides, which had antioxidant and anti-colon cancer activities that were strain specific and dependent on $\mathrm{pH}$, time, temperature, and bioactive peptide concentration (Elfahri et al., 2015).

\section{Outcome of Selected Clinical Trials to Determine the Effectivity of Probiotic Yogurt}

The scientific evidence to corroborate the claimed health benefits of fermented products is scanty, due to the huge finances and skills required for such activities (Marsh et al., 2014). Providing scientific evidence (investigative outcomes) is not the core business of the food industry. This then begs a strong working relationship between research institutions and the food industry. Proving health claims of fermented beverages (dairy or nondairy) is of huge interest to the regulatory bodies, and it ought to be part and parcel of research relating to functional food development.

Table 6 summarizes clinical trials that indicate the potential effect of consuming probiotic functional yogurt. Summarized reports in Table 6 suggest a strong link between microbial composition, cell concentration, and benefits to the human host, which implies that the health benefits of fermented beverages may be due to 3 possibilities: probiotic content, antimicrobial metabolites, and breakdown of complex food molecules (Marsh et al., 2014).

When yogurt containing LGG was consumed for 8 weeks by renal patients in a randomized controlled trial, vancomycin resistant enterococci were all cleared (Hill et al., 2017). Intake of yogurt incorporated with probiotic strains B. lactis $\mathrm{Bb} 12$ and L. acidophilus LA5 during a treatment period of 8 wk was observed to reduce blood glucose levels and endothelial dysfunction 
Nyanzi et al.: INVITED REVIEW: PROBIOTIC YOGURT

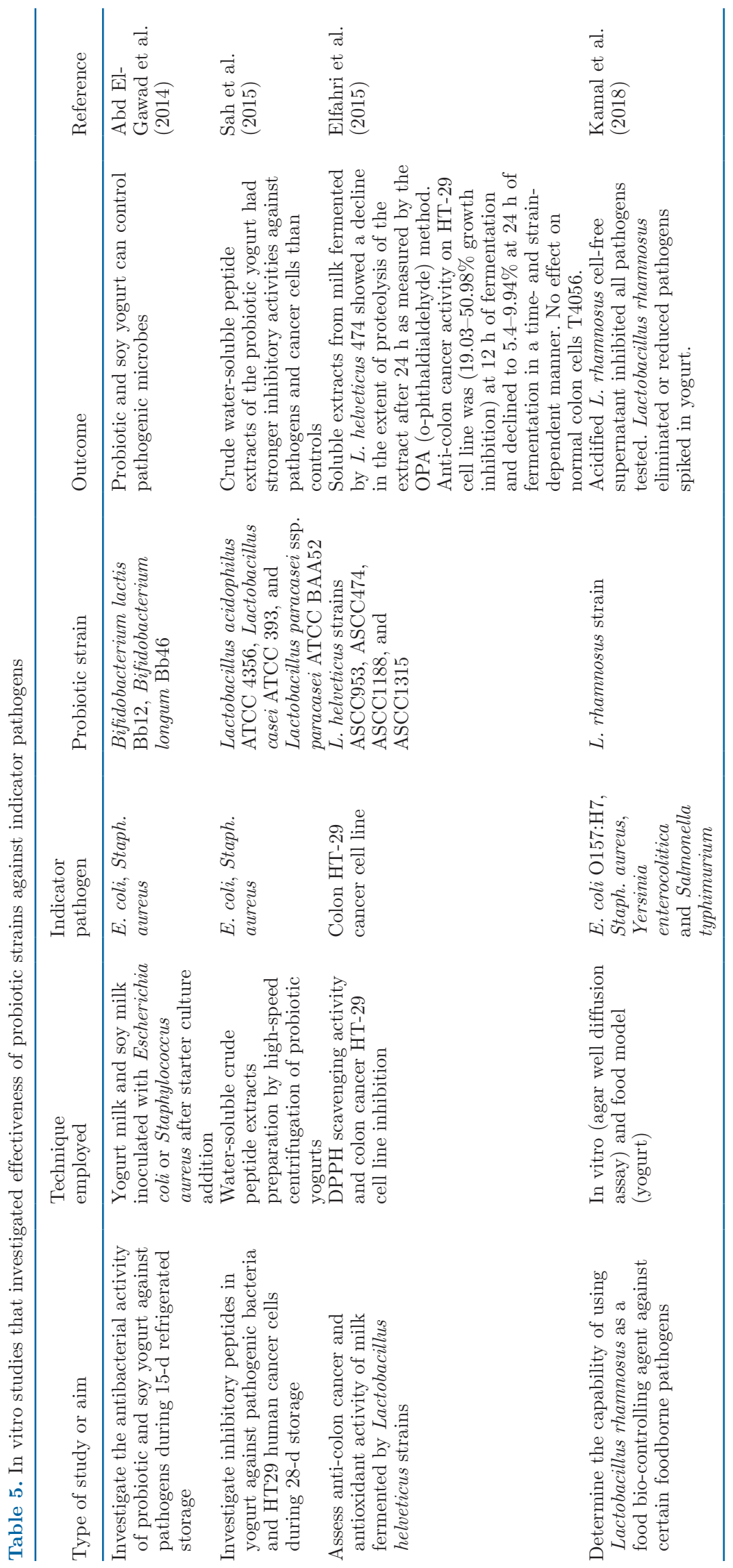


Nyanzi et al.: INVITED REVIEW: PROBIOTIC YOGURT

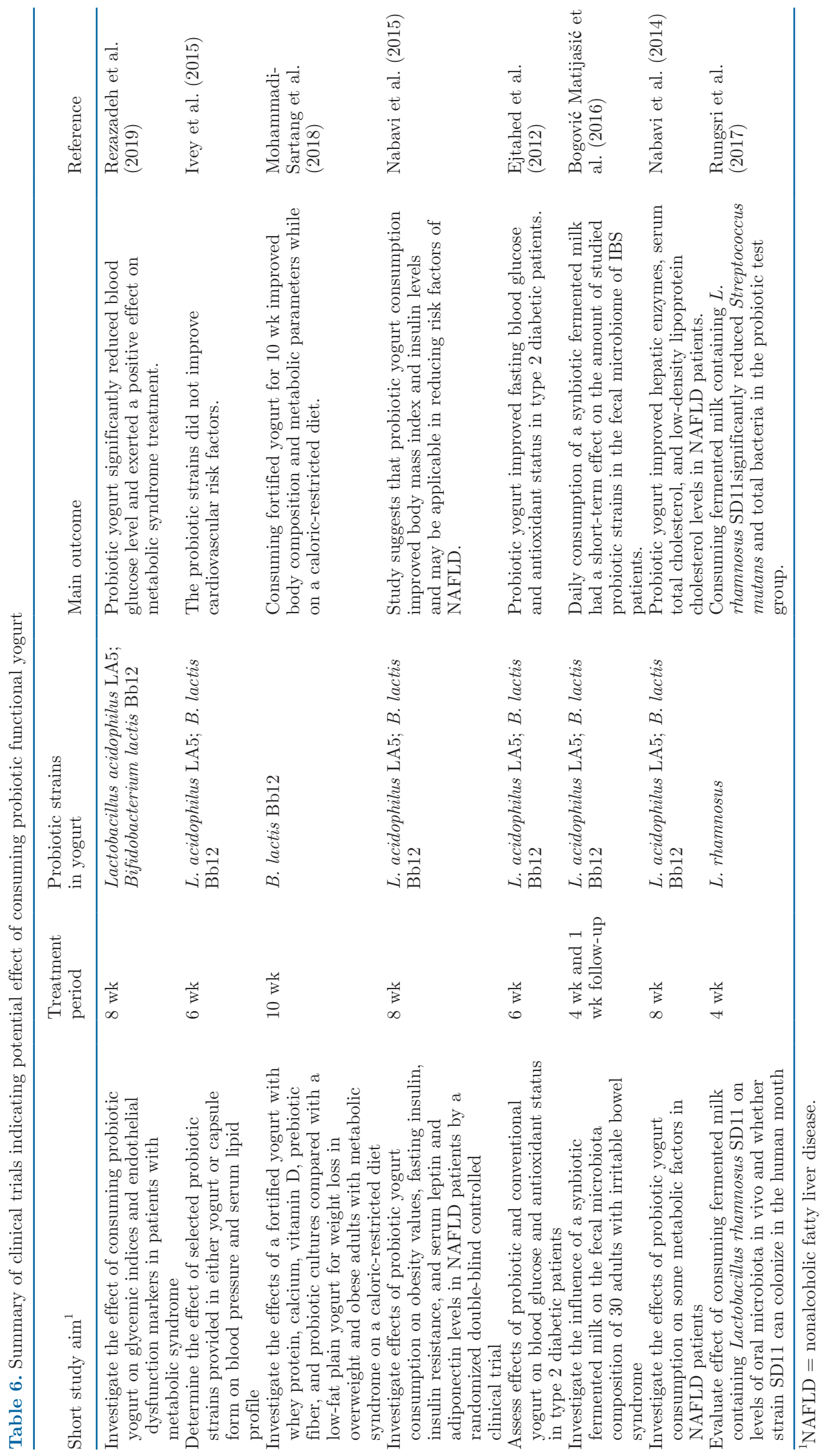


in relation to vascular cell adhesion molecule (marker) in persons with metabolic syndrome (Rezazadeh et al., 2019).

Rungsri et al. (2017) observed that daily consumption of fermented milk with added L. rhamnosus SD11 reduced Streptococcus mutans and total bacteria in the mouth of participants, and the levels of lactobacilli significantly increased in the probiotic group compared with the control groups. Other reports indicate that lactobacilli are able to prevent oral health challenges including dental caries (Laleman et al., 2014), periodontitis (Teughels et al., 2013), halitosis (Suzuki et al., 2014), and gingivitis (Rungsri et al., 2017). The mechanism relates to enhancement of friendly microbiota and inhibition of pathogens from adhering to the mucosa in the buccal cavity (Piwat et al., 2015). Inhibition may also result from the production of bacteriocins, organic acids, and antimicrobial proteins (Wannun et al., 2016). Providing clinical evidence may be hampered by the financial resources, multiple participants, and interdepartmental involvement of skilled personnel (nurses, nutritionists, dieticians, food scientists, and clinical associates) required to provide corroborated findings. Large-scale genome-wide analysis demonstrates that closely related LAB strains occur in both food and gut environments and provides unprecedented evidence that fermented foods can be regarded as a possible source of LAB for the gut microbiome (Pasolli et al., 2020).

\section{CONCLUSIONS AND RECOMMENDATIONS}

Fermentation of yogurt is beneficial, as it leads to low $\mathrm{pH}$ and harsh conditions for some foodborne pathogens, and improved sensory attributes, but this is microbial species or strain dependent. Organic acids attributed to fermentation may affect yogurt's viscosity and gelling properties.

The potential health benefits of strains claimed to be probiotic and GRAS were presented. Yogurt is a vehicle, arguably the most preferred, to deliver probiotics to the health-conscious consumer. Manufacturers of probiotic beverages need to ensure conformance to regulations.

Development of probiotic yogurt requires selection of strains with sound probiotic properties, safety, technological, sensory and functional properties. In terms of safety, strains of Lactobacillus and Bifidobacterium genera are GRAS. Safety encompasses delineative molecular identification, absence of transferable antibiotic resistance genes and hemolysis by the probiotic organisms.

Sensory attributes of probiotic yogurt can negatively affect consumer acceptability. Hence, probiotic strains selected need to improve sensory quality and be technologically suitable for viability to be above the recommended therapeutic minimum during processing and storage conditions.

Evidence of efficacy or clinical outcomes must be submitted to regulatory authorities for consideration of functional claim approval. Claims solely based on in vitro and in vivo animal models are considered inadequate. Efficacy of the probiotic strain(s) in yogurt must be investigated, confirmed and approved in accordance with well-designed human clinical trials.

The generally accepted therapeutic minimum is $10^{6}$ $\mathrm{cfu} / \mathrm{mL}$ for probiotic strains in yogurt over a period of 28 to $30 \mathrm{~d}$ of cold storage and probiotic yogurt should comply with regulations. The use of the word probiotic on product labels is restricted in some countries such as South Africa. In the EU, using the word probiotic on a label is a health claim, and the EFSA requires health claim approval, contrary to the FDA's stance that allows the use of the term probiotic. Countries such as South Africa need to clarify contradicting clauses in regulations promulgated by different government departments in relation to minimum starter and probiotic viability and whether probiotic strains may be added to yogurt.

The culture-dependent plate count method is most often used to enumerate viable cells in products such as yogurt; however, the VBNC (viable and stressed cell count) may not be enumerated. Probiotic and yogurt cultures are closely related and may not easily be differentiated during enumeration, unless selective or differential plate count methods for yogurt are standardized.

Flow cytometry is neither a culture-dependent technique nor a molecular-based approach to assessing probiotic cell content in yogurt, and the FC method can differentiate between viable and damaged or dead cells by employing the right fluorescence dyes. Cultureindependent techniques rely on nucleic acid analysis, and they include PCR, RT-PCR, and RT-qPCR. Differentiating between viable and stressed (VBNC) cells requires expertise in molecular biology. Use of EMAPCR and PMA-PCR provide alternative techniques for estimating viable cells (dependent on good integrity of the cell walls). The DNA of damaged cells is intercalated with dyes resulting in a lower nonstressed (viable) cell count.

The NGS approaches can be employed to determine the microbial diversity and proportion of species composition in probiotic yogurt. However, the NGS approaches may not reveal if DNA results obtained are from viable cells only and not from stressed (VBNC) cells, hence, employing plate count methods can counter-check viability. The NGS approaches require advanced training in bioinformatics skills, but they 
reliably confirm whether probiotic yogurt conforms to regulations.

\section{ACKNOWLEDGMENTS}

MilkSA (Pretoria, South Africa) is acknowledged for funding the study and the postdoctoral fellowship for the first author at the University of Pretoria. The views expressed are not those of the funding organization. None of the authors have any conflicts of interest with regard to views expressed in this article.

\section{REFERENCES}

Abd El-Gawad, I. A., E. M. El-Sayed, H. M. El-Zeini, S. A. Hafez, and F. A. Saleh. 2014. Antibacterial activity of probiotic yoghurt and soy-yoghurt against Escherichia coli and Staphylococcus aureus. J. Nutr. Food Sci. 4:1000303.

Amakiri, A. C., L. Kalombo, and M. S. Thantsha. 2015. Lyophilised vegetal BM 297 ATO-Inulin lipid-based synbiotic microparticles containing Bifidobacterium longum LMG 13197: Design and characterisation. J. Microencapsul. 32:820-827. https://doi.org/10 $.3109 / 02652048.2015 .1094534$.

Antunes, A. E. C., T. F. Cazetto, and H. M. A. Bolini. 2005. Viability of probiotic microorganisms during storage, postacidification and sensory analysis of fat-free yogurts with added whey protein concentrate. Int. J. Dairy Technol. 58:169-173.

Aryana, K. J., and D. W. Olson. 2017. A 100-year review: Yoghurt and other cultured dairy products. J. Dairy Sci. 100:9987-10013. https: //doi.org/10.3168/jds.2017-12981.

Baruzzi, F., S. de Candia, L. Qintieri, L. Caputo, and F. De Leo. 2017. Development of a synbiotic beverage enriched with bifidobacteria strains and fortified with whey proteins. Front. Microbiol. https: /doi.org/10.3389/fmicb.2017.00640.

Beristain-Bauza, S. C., E. Mani-López, E. Palou, and A. López-Malo. 2016. Antimicrobial activity and physical properties of protein films added with cell-free supernatant of Lactobacillus rhamnosus. Food Control 62:44-51. https://doi.org/10.1016/j.foodcont.2015 .10.007.

Bindels, L. B., N. M. Delzenne, P. D. Cani, and J. Walter. 2015. Towards a more comprehensive concept for prebiotics. Nat. Rev. Gastroenterol. Hepatol. 12:303-310.

Bisanz, J. E., J. M. Macklaim, G. B. Gloor, and G. Reid. 2014. Bacterial metatranscriptome analysis of a probiotic yoghurt using an RNA-Seq approach. Int. Dairy J. 39:284-292. https://doi.org/10 .1016/j.idairyj.2014.07.010.

Bogovič Matijašić, B., T. Obermajer, L. Lipoglavšek, T. Sernel, I. Locatelli, M. Kos, A. Šmid, and I. Rogelj. 2016. Effects of synbiotic fermented milk containing Lactobacillus acidophilus La-5 and Bifidobacterium animalis ssp. lactis BB-12 on the fecal microbiota of adults with irritable bowel syndrome: A randomized double-blind, placebo-controlled trial. J. Dairy Sci. 99:5008-5021. https://doi .org/10.3168/jds.2015-10743.

Bustos, A. Y., L. Saavedra, G. F. de Valdez, R. R. Raya, and M. P. Taranto. 2012. Relationship between bile salt hydrolase activity, changes in the internal $\mathrm{pH}$ and tolerance to bile acids in lactic acid bacteria. Biotechnol. Lett. 34:1511-1518. https://doi.org/10.1007/ s10529-012-0932-5.

Champagne, C. P., A. Gomes da Cruz, and M. Daga. 2018. Strategies to improve the functionality of probiotics in supplements and foods. Curr. Opin. Food Sci. 22:160-166. https://doi.org/10.1016/ j.cofs.2018.04.008.

Chandan, R. C., A. Gandhi, and N. P. Shah. 2017. Yoghurt: Historical background, health benefits and global trade. In Yoghurt in Health and Disease Prevention. N. P. Shah, ed. Academic Press, London, UK.
Chen, C.-Y., X. Yan, S. Wang, and C. R. Jackson. 2015. Application of metagenomic technologies for antimicrobial resistance and food safety research and beyond. Pages 401-422 in Antimicrobial Resistance and Food Safety. Academic Press, London, UK.

Chen, Y. F., W. J. Zhao, R. N. Wu, Z. H. Sun, W. Y. Zhang, J. C. Wang, M. Bilige, and H. P. Zhang. 2014. Proteome analysis of Lactobacillus helveticus H9 during growth in skim milk. J. Dairy Sci. 97:7413-7425. https://doi.org/10.3168/jds.2014-8520.

Cruz, A. G., W. F. Castro, J. A. F. Faria, S. Bogusz Jr, D. Granato, R. M. S. Celeguini, J. Lima-Pallone, and H. T. Godoy. 2012. Glucose oxidase: A potential option to decrease the oxidative stress in stirred probiotic yoghurt. Lebensm. Wiss. Technol. 47:512-515. https://doi.org/10.1016/j.lwt.2012.01.037.

Cutrim, C. S., R. F. de Barros, M. P. da Costa, R. M. Franco, C. A. Conte-Junior, and M. A. S. Cortez. 2016. Survival of Escherichia coli O157:H7 during manufacture and storage of traditional and low lactose yogurt. Lebensm. Wiss. Technol. 70:178-184. https:// doi.org/10.1016/j.lwt.2016.02.047.

Davis, C. 2014. Enumeration of probiotic strains: Review of culturedependent and alternative techniques to quantify viable bacteria. J. Microbiol. Methods 103:9-17. https://doi.org/10.1016/j.mimet .2014.04.012.

de Simone, C. 2019. The unregulated probiotic market. Clin. Gastroenterol. Hepatol. 17:809-817. https://doi.org/10.1016/j.cgh.2018 .01 .018 .

Doern, C. D., S. T. Nguyen, F. Afolabi, and C. A. D. Burnham. 2014. Probiotic-associated aspiration pneumonia due to Lactobacillus rhamnosus. J. Clin. Microbiol. 52:3124-3126. https://doi.org/10 .1128/JCM.01065-14.

Donkor, O. N., A. Henriksson, T. Vasiljevic, and N. P. Shah. 2006. Effect of acidification on the activity of probiotics in yoghurt during cold storage. Int. Dairy J. 16:1181-1189.

Ejtahed, H. S., J. Mohtadi-Nia, A. Homayouni-Rad, M. Niafar, M. Asghari-Jafarabadi, and V. Mofid. 2012. Probiotic yogurt improves antioxidant status in type 2 diabetic patients. Nutrition 28:539-543. https://doi.org/10.1016/j.nut.2011.08.013.

El-Fattah, A. A., S. Sakr, S. El-Dieb, and H. Elkashef. 2016. Angiotensin-converting enzyme inhibition and antioxidant activity of commercial dairy starter cultures. Food Sci. Biotechnol. 25:1745-1751. https://doi.org/10.1007/s10068-016-0266-5.

El-Fattah, A. A., S. Sakr, S. El-Dieb, and H. Elkashef. 2018. Developing functional yogurt rich in bioactive peptides and gamma-aminobutyric acid related to cardiovascular health. Lebensm. Wiss. Technol. 98:390-397. https://doi.org/10.1016/j.lwt.2018.09.022.

Elfahri, K. R., T. Vasiljevic, T. Yeager, and O. N. Donkor. 2016. Anticolon cancer and antioxidant activities of bovine skim milk fermented by selected Lactobacillus helveticus strains. J. Dairy Sci. 99:31-40. https://doi.org/10.3168/jds.2015-10160.

Eratte, D., K. Dowling, C. J. Barrow, and B. Adhikari. 2018. Recent advances in the microencapsulation of omega-3 oil and probiotic bacteria through complex coecervation: A review. Trends Food Sci. Technol. 71:121-131. https://doi.org/10.1016/j.tifs.2017.10 .014 .

Espírito-Santo, A. P., P. Perego, A. Converti, and M. N. Oliveira. 2012. Influence of milk type and addition of passion fruit peel powder on fermentation kinetics, texture profile and bacterial viability in probiotic yoghurt. Lebensm. Wiss. Technol. 47:393-399.

Faihst, T.-J., J. Myburgh, C. Bothma, C. Hugo, and A. Hugo. 2017 Effect of conjugated linoleic acid supplementation on the microbial, physical, chemical and sensory properties of yoghurt. Int. J. Dairy Technol. 70:228-236. https://doi.org/10.1111/1471-0307 .12325 .

FAO/WHO (Food and Agriculture Organization of the United Nations/World Health Organization). 2002. Guidelines for the evaluation of probiotics in food. Report of a joint FAO/WHO working group on drafting guidelines for the evaluation of probiotics in food. Food and Agriculture Organization of the United Nations, Rome, Italy, and World Health Organization, Geneva, Switzerland.

Fazilah, N. F., A. B. Ariff, M. E. Khayat, L. Rios-Solis, and M. Halim. 2018. Influence of probiotics, prebiotics, synbiotics and bioactive 
phytochemicals on the formulation of functional yogurt. J. Funct. Foods 48:387-399. https://doi.org/10.1016/j.jff.2018.07.039.

Fijan, S. 2014. Microorganisms with claimed probiotic properties: An overview of recent literature. Int. J. Environ. Res. Public Health 11:4745-4767. https://doi.org/10.3390/ijerph110504745.

Fittipaldi, M., A. Nocker, and F. Codony. 2012. Progress in understanding preferential detection of live cells using viability dyes in combination with DNA amplification. J. Microbiol. Methods 91:276-289. https://doi.org/10.1016/j.mimet.2012.08.007.

Foligné, B., C. Daniel, and B. Pot. 2013. Probiotics from research to market: The possibilities, risks and challenges. Curr. Opin. Microbiol. 16:284-292. https://doi.org/10.1016/j.mib.2013.06.008.

Gebara, C., M. C. E. Ribeiro, K. S. Chaves, A. L. N. Gandara, and M. L. Gigante. 2015. Effectiveness of different methodologies for the selective enumeration of Lactobacillus acidophilus La5 from yoghurt and Prato cheese. Lebensm. Wiss. Technol. 64:508-513. https://doi.org/10.1016/j.lwt.2015.04.061.

Geng, J., C. Chiron, and J. Combrisson. 2014. Rapid and specific enumeration of viable Bifidobacterium in dairy products based on flow cytometry technology: A proof of concept study. Int. Dairy J. 37:1-4. https://doi.org/10.1016/j.idairyj.2014.02.002.

Gibson, G. R., R. Hutkins, M. E. Sanders, S. L. Prescott, R. A. Reimer, S. J. Salminen, K. Scott, C. Stanton, K. S. Swanson, P. D. Cani, K. Verbeke, and G. Reid. 2017. The International Scientific Association for Probiotics and Prebiotics (ISAPP) consensus statement on the definition and scope of prebiotics. Nat. Rev. Gastroenterol. Hepatol. 14:491-502.

Hekmat, S., H. Soltani, and G. Reid. 2009. Growth and survival of Lactobacillus reuteri $\mathrm{RC}-14$ and Lactobacillus rhamnosus GR-1 in yogurt for use as a functional food. Innov. Food Sci. Emerg. Technol. 10:293-296. https://doi.org/10.1016/j.ifset.2008.10.007.

Hill, C., F. Guarner, G. Reid, G. R. Gibson, D. J. Merenstein, B. Pot, L. Morelli, R. B. Canani, H. J. Flint, S. Salminen, P. C. Calder, and M. E. Sanders. 2014. The International Scientific Association for probiotics and prebiotics consensus statement on the scope and appropriate use of the term probiotic. Nat. Rev. Gastro. Hepatol. 11:506-514. https://doi.org/10.1038/nrgastro.2014.66.

Hill, D., R. Ross, E. Arendt, and C. Stanton. 2017. Microbiology of yogurt and bio-yogurts containing probiotics and prebiotics. In Yoghurt in Health and Disease Prevention. N. P. Shah. Academic Press, London, UK.

Hussain, M., F. R. Awan, A. Gujjar, S. Hafeez, and M. Islam. 2018. A case control association study of $A C E$ gene polymorphism (I/D) with hypertension in Punjabi population from Faisalabad, Pakistan. Clin. Exp. Hypertens. 40:186-191. https://doi.org/10.1080/ 10641963.2017.1356842.

IDF (International Dairy Federation). 1995. Fermented and non-fermented milk products - detection and enumeration of Lactobacillus acidophilus - culture media. Bulletin IDF 306:23-33.

Iglesias, M. B., I. Viñas, P. Colás-Medà, C. Collazo, J. C. E. Serrano, and M. Abadias. 2017. Adhesion and invasion of Listeria monocytogenes and interaction with Lactobacillus rhamnosus GG after habituation on fresh-cut pear. J. Funct. Foods 34:453-460. https:/ /doi.org/10.1016/j.jff.2017.05.011.

Illupapalayam, V. V., S. C. Smith, and S. Gamlath. 2014. Consumer acceptability and antioxidant potential of probiotic-yogurt with spices. Lebensm. Wiss. Technol. 55:255-262. https://doi.org/10 $.1016 /$ j.lwt.2013.09.025.

Innocente, N., M. Biasutti, F. Rita, R. Brichese, G. Comi, and L. Iacumin. 2016. Effect of indigenous Lactobacillus rhamnosus isolated from bovine milk on microbiological characteristics and aromatic profile of traditional yogurt. Lebensm. Wiss. Technol. 66:158-164. https://doi.org/10.1016/j.lwt.2015.10.031.

ISO (International Organization for Standardization). 2002. Milk products - Enumeration of Lactobacillus acidophilus - Colony count technique at $43^{\circ} \mathrm{C}$. ISO 20128:2002 (IDF 192:2002). ISO, Geneva, Switzerland.

ISO. (International Organization for Standardization). 2006. ISO 20128:2006 [IDF 192:2006]. Milk products-Enumeration of presumptive Lactobacillus acidophilus on a selective medium-Colony-count technique at 37 degrees C. ISO, Geneva, Switzerland.
Ivey, K. L., J. M. Hodgson, D. A. Kerr, P. L. Thompson, B. Stojceski, and R. L. Prince. 2015. The effect of yoghurt and its probiotics on blood pressure and serum lipid profile; a randomized controlled trial. Nutr. Metab. Cardiovasc. Dis. 25:46-51. https://doi.org/10 .1016/j.numecd.2014.07.012.

Iwatani, S., and N. Yamamoto. 2019. Functional food products in Japan: A review. Food Sci. Hum. Wellness 8:96-101. https://doi.org/ 10.1016/j.fshw.2019.03.011.

Januário, J. G. B., I. C. F. da Silva, A. S. de Oliveira, J. F. de Oliveira, J. N. Dionísio, S. J. Klososki, and T. C. Pimentel. 2017. Probiotic yoghurt flavored with organic beet with carrot, cassava, sweet potato or corn juice: Physicochemical and texture evaluation, probiotic viability and acceptance. Int. Food Res. J. 24:359-366.

Jungersen, M., A. Wind, E. Johansen, J. E. Christensen, B. StuerLauridsen, and D. Eskesen. 2014. The science behind the probiotic strain Bifidobacterium animalis subsp. lactis BB-12. Microorganisms $2: 92-110$

Kamal, R. M., M. E. Alnakip, S. F. Abd El Aal, and M. A. Bayoumi. 2018. Bio-controlling capability of probiotic strain Lactobacillus rhamnosus against some common foodborne pathogens in yoghurt. Int. Dairy J. 85:1-7. https://doi.org/10.1016/j.idairyj.2018.04.007.

Kara, I., F. Yildirim, Ö. Özgen, S. Erganis, M. Aydoğdu, M. Dizbay, G. Gürsel, and A. Kalkanci. 2018. Saccharomyces cerevisiae fungemia after probiotic treatment in an intensive care unit patient. J. Mycol. Med. 28:218-221. https://doi.org/10.1016/j.mycmed.2017 .09 .003 .

Kerry, R. G., J. K. Patra, S. Gouda, Y. Park, H.-S. Shin, and G. Das. 2018. Benefaction of probiotics for human health: A review. J Food Drug Anal. 26:927-939.

Kilara, A. 2017. Regulatory aspects of yogurt. In Yoghurt in Health and Disease Prevention. N. P. Shah, ed. Academic Press, London, UK.

Kothari, D., S. Patel, and S.-K. Kim. 2019. Probiotic supplements might not be universally-effective and safe: A review. Biomed. Pharmacother. 111:537-547. https://doi.org/10.1016/j.biopha .2018.12.104.

Kumar, H., S. Salminen, H. Verhagen, I. Rowland, J. Heimbach, S. Bañares, T. Young, K. Nomoto, and M. Lalonde. 2015. Novel probiotics and prebiotics: Road to the market. Curr. Opin. Biotechnol. 32:99-103. https://doi.org/10.1016/j.copbio.2014.11.021.

Laidlaw, A. M., M. G. Gänzle, and X. Yang. 2019. Comparative assessment of qPCR enumeration methods that discriminate between live and dead Escherichia coli 0157:H7 on beef. Food Microbiol. 79:41-47. https://doi.org/10.1016/j.fm.2018.11.002.

Laleman, I., V. Detailleur, D. E. Slot, V. Slomka, M. Quirynen, and W. Teughels. 2014. Probiotics reduce mutans streptococci counts in humans: A systematic review and meta-analysis. Clin. Oral Investig. 18:1539-1552. https://doi.org/10.1007/s00784-014-1228-z.

Lugli, G. A., M. Mangifesta, L. Mancabelli, C. Milani, F. Turroni, A Viappiani, D. van Sinderen, and M. Ventura. 2019. Compositional assessment of bacterial communities in probiotic supplements by means of metagenomic techniques. Int. J. Food Microbiol. 294:1-9. https://doi.org/10.1016/j.ijfoodmicro.2019.01.011.

Marafon, A. P., A. Sumi, M. R. Alcântara, A. Y. Tamime, and M. Nogueira de Oliveira. 2011. Optimization of the rheological properties of probiotic yoghurts supplemented with milk proteins. Lebensm. Wiss. Technol. 44:511-519. https://doi.org/10.1016/j.lwt 2010.09.005.

Marsh, A. J., C. Hill, R. P. Ross, and P. D. Cotter. 2014. Fermented beverages with health-promoting potential: Past and future perspectives. Trends Food Sci. Technol. 38:113-124. https://doi.org/ 10.1016/j.tifs.2014.05.002

Martin, I. W., R. Tonner, J. Trivedi, H. Miller, R. Lee, X. Liang, L. Rotello, E. Isenbergh, J. Anderson, T. Perl, and S. X. Zhang. 2017. Saccharomyces boulardii probiotic-associated fungemia: Questioning the safety of this preventive probiotic's use. Diagn. Microbiol. Infect. Dis. 87:286-288. https://doi.org/10.1016/j.diagmicrobio .2016.12.004.

Masco, L., M. Ventura, R. Zink, G. Huys, and J. Swings. 2004. Polyphasic taxonomic analysis of Bifidobacterium animalis and Bifidobacterium lactis reveals relatedness at the subspecies level: reclas- 
sification of Bifidobacterium animalis as Bifidobacterium animalis subsp. animalis subsp. nov. and Bifidobacterium lactis as Bifidobacterium animalis subsp. lactis subsp. nov. Int. J. Syst. Evol. Microbiol. 54:1137-1143.

Miranda, R. O., A. F. De Carvalho, and L. A. Nero. 2014. Development of a selective culture medium for bifidobacteria, raffinosepropionate lithium mupirocin (RP-MUP) and assessment of its usage with petrifilm ${ }^{\mathrm{TM}}$ aerobic count plates. Food Microbiol. 39:96-102.

Mohammadi-Sartang, M., N. Bellissimo, J. O. Totosy de Zepetnek, N. R. Brett, S. M. Mazloomi, M. Fararouie, A. Bedeltavana, M. Famouri, and Z. Mazloom. 2018. The effect of daily fortified yogurt consumption on weight loss in adults with metabolic syndrome: A 10-week randomized controlled trial. Nutr. Metab. Cardiovasc. Dis. 28:565-574. https://doi.org/10.1016/j.numecd.2018.03.001.

Moineau-Jean, A., C. P. Champagne, D. Roy, Y. Raymond, and G. LaPointe. 2019. Effect of Greek-style yoghurt manufacturing processes on starter and probiotic bacteria populations during storage. Int. Dairy J. 93:35-44. https://doi.org/10.1016/j.idairyj.2019 .02 .003 .

Morovic, W., A. A. Hibberd, B. Zabel, R. Barrangou, and B. Stahl. 2016. Genotyping by PCR and high-throughput sequencing of commercial probiotic products reveals composition biases. Front. Microbiol. 7:1747. https://doi.org/10.3389/fmicb.2016.01747.

Mousavi, M., A. Heshmati, A. D. Garmakhany, A. Vahidinia, and M. Taheri. 2019. Optimization of the viability of Lactobacillus acidophilus and physico-chemical, textural and sensorial characteristics of flaxseed-enriched stirred probiotic yogurt by using response surface methodology. Lebensm. Wiss. Technol. 102:80-88. https:// doi.org/10.1016/j.lwt.2018.12.023.

Mpofu, A., A. Linnemann, M. J. R. Nout, M. H. Zwietering, E. J, Smid, and H. M. W. den Besten. 2016. Inactivation of bacterial pathogens in yoba mutandabota, a dairy product fermented with the probiotic Lactobacillus rhamnosus yoba. Int. J. Food Microbiol. 217:42-48. https://doi.org/10.1016/j.ijfoodmicro.2015.09.016.

Mpofu, A., A. R. Linnemann, W. Sybesma, R. Kort, M. J. R. Nout, and E. J. Smid. 2014. Development of a locally sustainable functional food based on mutandabota, a traditional food in southern Africa. J. Dairy Sci. 97:2591-2599. https://doi.org/10.3168/jds $.2013-7593$

Muniandy, P., A. B. Shori, and A. S. Baba. 2016. Influence of green, white and black tea addition on the antioxidant acidity of probiotic yogurt during refrigerated storage. Food Packag. Shelf Life 8:1-8. https://doi.org/10.1016/j.fpsl.2016.02.002.

Nabavi, S., M. Rafraf, M.-H. Somi, A. Homayouni-Rad, and M. Asghari-Jafarabadi. 2014. Effects of probiotic yogurt consumption on metabolic factors in individuals with nonalcoholic fatty liver disease. J. Dairy Sci. 97:7386-7393. https://doi.org/10.3168/jds .2014-8500.

Nabavi, S., M. Rafraf, M.-H. Somi, A. Homayouni-Rad, and M. Asghari-Jafarabadi. 2015. Probiotic yogurt improves body mass index and fasting insulin levels without affecting serum leptin and adiponectin levels in non-alcoholic fatty liver disease (NAFLD). J. Funct. Foods 18:684-691. https://doi.org/10.1016/j.jff.2015.08 .031 .

Palomar, M. M., C. Maldonado Galdeano, and G. Perdigón. 2014. Influence of a probiotic lactobacillus strain on the intestinal ecosystem in a stress model mouse. Brain Behav. Immun. 35:77-85. https://doi.org/10.1016/j.bbi.2013.08.015.

Pasolli, E., F. De Filippis, I. E. Mauriello, F. Cumbo, A. M. Walsh, J. Leech, P. D. Cotter, N. Segata, and D. Ercolini. 2020. Large-scale genome-wide analysis links lactic acid bacteria from food with the gut microbiome. Nat. Commun. 11:1-2.

Patro, J. N., P. Ramachandran, T. Barnaba, M. K. Mammel, J. L. Lewis, and C. A. Elkins. 2016. Culture-independent metagenomic surveillance of commercially available probiotics with highthroughput next-generation sequencing. MSphere 1:e00057-e16. https://doi.org/10.1128/mSphere.00057-16.

Piwat, S., B. Sophatha, and R. Teanpaisan. 2015. An assessment of adhesion, aggregation, and surface charges of Lactobacillus strains derived from the human oral cavity. Lett. Appl. Microbiol. 61:98105. https://doi.org/10.1111/lam.12434.

Prado, F. C., J. L. Parada, A. Pandey, and C. R. Soccol. 2008. Trends in non-dairy probiotic beverages. Food Res. Int. 41:111-123. https: //doi.org/10.1016/j.foodres.2007.10.010.

Rada, V., and J. Koc. 2000. The use of mupirocin for selective enumeration of bifidobacteria in fermented milk products. Milchwissenschaft 55:65-67.

Ray, R. C., and V. K. Joshi. 2015. Fermented foods: Past, present and future. In Microorganisms and Fermentation of Traditional Foods. R. C. Ray and D. Montet, ed. CRS Press, Boca Raton, FL.

Raymond, Y., and C. P. Champagne. 2015. The use of flow cytometry to accurately ascertain total and viable counts of Lactobacillus rhamnosus in chocolate. Food Microbiol. 46:176-183. https://doi .org/10.1016/j.fm.2014.07.002.

Rezazadeh, L., B. P. Gargari, M. A. Jafarabadi, and B. Alipour. 2019. Effects of probiotic yogurt on glycemic indexes and endothelial dysfunction markers in patients with metabolic syndrome. Nutrition 62:162-168. https://doi.org/10.1016/j.nut.2018.12.011.

Ribeiro, M. C., K. S. Chaves, C. Gebara, F. N. S. Infante, C. R. F. Grosso, and M. L. Gigante. 2014. Effect of microencapsulation of Lactobacillus acidophilus LA-5 on physicochemical, sensory and microbiological characteristics of stirred probiotic yoghurt. Food Res. Int. 66:424-431. https://doi.org/10.1016/j.foodres.2014.10 .019 .

Rodríguez-Nogales, A., E. Algieri, T. Vezza, N. Garrido-Mesa, M. Olivares, M. Comalada, C. Riccardi, M. P. Utrilla, M. E. Rodríguez-Cabezas, and J. Galvez. 2015. The viability of Lactobacillus fermentum CECT5716 is not essential to exert intestinal anti-inflammatory properties. Food Funct. 6:1176-1184. https://doi.org/ 10.1039/C4FO00938J.

Rungsri, P., N. Akkarachaneeyakorn, M. Wongsuwanlert, S. Piwat, P. Nantarakchaikul, and R. Teanpaisan. 2017. Effect of fermented milk containing Lactobacillus rhamnosus SD11 on oral microbiota of healthy volunteers: A randomized clinical trial. J. Dairy Sci. 100:7780-7787. https://doi.org/10.3168/jds.2017-12961.

Saarela, M. H. 2019. Safety aspects of next generation probiotics. Curr. Opin. Food Sci. 30:8-13. https://doi.org/10.1016/j.cofs.2018 .09.001.

Saccaro, D. M., C. Y. Hirota, A. Y. Tamime, and M. N. Oliveira. 2012. Evaluation of different selective media for enumeration of probiotic microorganisms in combination with yoghurt starter cultures in fermented milk. Afr. J. Microbiol. Res. 6:2239-2245.

Sah, B. N. P., T. Vasiljevic, S. Mckechnie, and O. N. Donkor. 2016. Antibacterial and antiproliferative peptides in synbiotic yoghurtrelease and stability during refrigerated storage. J. Dairy Sci. 99:4233-4242. https://doi.org/10.3168/jds.2015-10499.

Sah, B. N. P., T. Vasiljevic, S. Mckechnie, and O. N. Donkor. 2016. Physicochemical, textural and rheological properties of probiotic yoghurt fortified with fibre-rich pineapple peel powder during refrigerated storage. Lebensm. Wiss. Technol. 65:978-986.

Santino, I., A. Alari, S. Bono, E. Teti, M. Marangi, A. Bernardini, L. Magrini, S. Di Somma, and A. Teggi. 2014. Saccharomyces cerevisiae fungemia, a possible consequence of the treatment of Clostridium difficile colitis with a probioticum. Int. J. Immunopathol. Pharmacol. 27:143-146.

Sarkar, S. 2018. Whether viable and dead probiotic are equally efficacious? Nutr. Food Sci. 48:285-300. https://doi.org/10.1108/NFS $-07-2017-0151$.

Segers, M. E., and S. Lebeer. 2014. Towards a better understanding of Lactobacillus rhamnosus GG-host interactions. Microb. Cell Fact. 13(Suppl 1):S7 http://www.microbialcellfactories.com/content/ 13/S1/S7.

Shao, Y., Z. Wang, Q. Bao, and H. Zhang. 2016. Application of propidium monoazide quantitative real-time PCR to quantify the viability of Lactobacillus delbrueckii ssp. bulgaricus. J. Dairy Sci. 99:9570-9580. https://doi.org/10.3168/jds.2016-11597.

Sotoudegan, F., M. Daniali, S. Hassani, S. Nikfar, and M. Abdollahi. 2019. Reappraisal of probiotics' safety in human. Food Chem. Toxicol. 129:22-29. https://doi.org/10.1016/j.fct.2019.04.032. 
South Africa Department of Agriculture, Forestry and Fisheries. 2015. Agricultural Product Standards Act, 1990 (Act No. 119 of 1990: Regulation R.260 of 2015): Regulations relating to the classification, packing and marking of dairy products and imitation dairy products intended for sale in the republic of South Africa: Amendment. Government Notice, page 5, Gazette No. 38615.

South Africa Department of Health. 1972. Foods, Cosmetics and Disinfectants Act, 1972 (Act No. 54 of 1972): Regulations relating to the labelling and advertising of foods: Amendment. Government Notice, page 3, Gazette No. 37695.

Suharto, E. L. S., I. I. Arief, and E. Taufik. 2016. Quality and antioxidant activity of yogurt supplemented with roselle during cold storage. Media Peternakan 39:82-89. https://doi.org/10.5398/medpet .2016.39.2.82.

Suzuki, N., M. Yoneda, K. Tanabe, A. Fujimoto, K. Iha, K. Seno, K. Yamada, T. Iwamoto, Y. Masuo, and T. Hirofuji. 2014. Lactobacillus salivarius WB21-containing tablets for the treatment of oral malodor: A double-blind, randomized, placebo-controlled crossover trial. Oral Surg. Oral Med. Oral Pathol. Oral Radiol. 117:462-470. https://doi.org/10.1016/j.oooo.2013.12.400.

Terpou, A., A. Bekatorou, M. Kanellaki, A. A. Koutinas, and P. Nigam. 2017. Enhanced probiotic viability and aromatic profile of yogurts producedusing wheat bran (Triticum aestivum) as cell immobilization carrier. Process Biochem. 55:1-10. https://doi.org/10 .1016/j.procbio.2017.01.013.

Teughels, W., A. Durukan, O. Ozcelik, M. Pauwels, M. Quirynen, and M. C. Haytac. 2013. Clinical and microbiological effects of Lactobacillus reuteri probiotics in the treatment of chronic periodontitis: A randomized placebo-controlled study. J. Clin. Periodontol. 40:1025-1035. https://doi.org/10.1111/jcpe.12155.

Tharmaraj, N., and N. P. Shah. 2003. Selective enumeration of Lactobacillus delbrueckii ssp. bulgaricus, Streptococcus thermophilus, Lactobacillus acidophilus, bifidobacteria, Lactobacillus casei, Lactobacillus rhamnosus and propionibacteria. J. Dairy Sci. 86:22882296.

Tripathi, M. K., and S. K. Giri. 2014. Probiotic functional foods: Survival of probiotics during processing and storage. J. Funct. Foods 9:225-241. https://doi.org/10.1016/j.jff.2014.04.030.

Turkmen, N., C. Akal, and B. Özer. 2019. Probiotic dairy-based beverages: A review. J. Funct. Foods 53:62-75. https://doi.org/10.1016/ j.jff.2018.12.004.

US FDA (Food and Drug Administration). 2019. Code of Federal Regulations Title 21, Volume 2, Revised as of April 1, 2019. Chapter 1, Subchapter B Food for human consumption. Part 131 Milk and Cream, Subpart B: Requirements for specific standardized milk and cream. Section 131.200 Yogurt.

Veiga, P., N. Pons, A. Agrawal, R. Oozeer, D. Guyonnet, R. Brazeilles, J.-M. Faurie, J. E. T. van Hylckama Vlieg, L. A. Houghton, P. J. Whorwell, S. D. Ehrlich, and S. P. Kennedy. 2014. Changes of the human gut microbiome induced by a fermented milk product. Sci. Rep. 4:6328. https://doi.org/10.1038/srep06328.
Verbeke, W., J. Scholderer, and L. Lahteenmaki. 2009. Consumer appeal of nutrition and health claims in three existing product concepts. Appetite 52:684-692. https://doi.org/10.1016/j.appet.2009 .03.007.

Vinderola, G., J. Reinheimer, and S. Salminen. 2019. The enumeration of probiotic issues: From unavailable standardised culture media to a recommended procedure? Int. Dairy J. 96:58-65. https://doi .org/10.1016/j.idairyj.2019.04.010.

Vlkova, E., H. Salmonova, V. Bunešová, M. Geigerová, V. Rada, and Ś. Musilová. 2015. A new medium containing mupirocin, acetic acid, and norfloxacin for the selective cultivation of bifidobacterial. Anaerobe 34:27-33.

Wannun, P., S. Piwat, and R. Teanpaisan. 2016. Purification, characterization, and optimum conditions of fermencin $\mathrm{SD}_{11}$, a bacteriocin produced by human orally Lactobacillus fermentum $\mathrm{SD}_{11}$. Appl. Biochem. Biotechnol. 179:572-582. https://doi.org/10.1007/ s12010-016-2014-y.

WHO/FAO. 2011. Codex alimentarius: Codex standards for fermented milks 243-2003. Pages 6-16 in Milk and Milk Products, second edition, World Health Organisation, Food and Agriculture Organisation of the United Nations, Rome, Italy.

Wilkinson, M. G. 2018. Flow cytometry as a potential method of measuring bacterial viability in probiotic products: A review. Trends Food Sci. Technol. 78:1-10. https://doi.org/10.1016/j.tifs.2018.05 .006 .

Yang, Y., A. Shevchenko, A. Knaust, I. Abuduresule, W. Li, X. Hu, C. Wang, and A. Shevchenko. 2014. Proteomics evidence for kefir dairy in Early Bronze Age China. J. Archaeol. Sci. 45:178-186. https://doi.org/10.1016/j.jas.2014.02.005.

Zhang, T., C. H. Jeong, W. N. Cheng, H. Bae, H. G. Seo, M. C. Petriello, and S. G. Han. 2019. Moringa extract enhances the fermentative, textural, and bioactive properties of yoghurt. Lebensm. Wiss. Technol. 101:276-284. https://doi.org/10.1016/j.lwt.2018.11.010.

Zheng, J., S. Wittouck, E. Salvetti, C. M. A. P. Franz, H. M. B. Harris, P. Mattarelli, P. W. O. Toole, B. Pot, P. Vandamme, J. Walter, K. Watanabe, S. Wuyts, G. E. Felis, M. G. Gänzle, and S. Lebeer. 2020. A taxonomic note on the genus Lactobacillus: Description of 23 novel genera, emended description of the genus Lactobacillus beijerinck 1901, and union of Lactobacillaceae and Leuconostocaceae. Int. J. Syst. Evol. Microbiol. 70:2782-2858.

Zhou, T., R. Huo, L.-Y. Kwok, C. Li, Y. Ma, Z. Mi, and Y. Chen. 2019. Effects of applying Lactobacillus helveticus H9 as adjunct starter culture in yogurt fermentation and storage. J. Dairy Sci. 102:223-235. https://doi.org/10.3168/jds.2018-14602.

\section{ORCIDS}

Richard Nyanzi @ https://orcid.org/0000-0001-5997-350X

Piet J. Jooste @ $\odot$ https://orcid.org/0000-0003-4520-8393

Elna M. Buys @ https://orcid.org/0000-0001-7836-9295 